Chapman University

Chapman University Digital Commons

Pharmacy Faculty Articles and Research

School of Pharmacy

$9-2003$

\title{
Immortalized Epithelial Cells from Human Autosomal Dominant Polycystic Kidney Cysts
}

Mahmoud Loghman-Adham

St Louis University

Surya M. Nauli

Chapman University, nauli@chapman.edu

Carlos E. Soto

St Louis University

Barbara Kariuki

St Louis University

Jing Zhou

University of Chicago

Follow this and additional works at: http://digitalcommons.chapman.edu/pharmacy_articles

Part of the Endocrine System Commons, Genetic Phenomena Commons, Medical Genetics Commons, and the Urogenital System Commons

\section{Recommended Citation}

Loghman-Adham M, Nauli SM, Soto CE, Kariuki B, Zhou J. Immortalized epithelial cells from human autosomal dominant polycystic kidney cysts. Am J Physiol Renal Physiol. 2003 Sep;285(3):F397-412.

DOI:10.1152/ajprenal.00310.2002 


\section{Immortalized Epithelial Cells from Human Autosomal Dominant Polycystic Kidney Cysts}

\section{Comments}

This article was originally published in American Journal of Physiology - Renal Physiology, volume 285, issue 3, in 2003. DOI: 10.1152/ajprenal.00310.2002

\section{Copyright}

American Physiological Society 


\title{
Immortalized epithelial cells from human autosomal dominant polycystic kidney cysts
}

\author{
Mahmoud Loghman-Adham, Surya M. Nauli, \\ Carlos E. Soto, Barbara Kariuki, and Jing Zhou \\ Department of Pediatrics and Pediatric Research Institute, Saint Louis University \\ School of Medicine, St. Louis, Missouri 63104; and Harvard Institutes \\ of Medicine, Harvard Medical School, Boston, Massachusetts 02115 \\ Submitted 28 August 2002; accepted in final form 29 April 2003
}

Loghman-Adham, Mahmoud, Surya M. Nauli, Carlos E. Soto, Barbara Kariuki, and Jing Zhou. Immortalized epithelial cells from human autosomal dominant polycystic kidney cysts. Am J Physiol Renal Physiol 285: F397-F412, 2003. First published May 6, 2003; 10.1152/ajprenal.00310. 2002.-Autosomal dominant polycystic kidney disease (ADPKD) is the result of mutations in one allele of the PKD1 or PKD2 genes, followed by "second hit" somatic mutations of the other allele in renal tubule cells. Continued proliferation of clonal cells originating from different nephron segments leads to cyst formation. In vitro studies of the mechanisms of cyst formation have been hampered by the scarcity of nephrectomy specimens and the limited life span of cyst-derived cells in primary culture. We describe the development of a series of immortalized epithelial cell lines from over 30 individual renal cysts obtained from 11 patients with $\mathrm{AD}$ PKD. The cells were immortalized with either wild-type (WT) or temperature-sensitive (TS) recombinant adeno-simian virus (SV)40 viruses. SV40 DNA integration into the cell genome was verified by PCR analysis. The cells have been passaged over 50 times with no apparent phenotypic change. By light microscopy, the cells appear pleomorphic but mostly polygonal and resemble the primary cultures. Transmission electron microscopy shows polarized epithelia with tight junctions. The SV40 large T antigen was detected by immunocytochemistry and by Western blot analysis at $37^{\circ} \mathrm{C}$ in the WT cell lines and at $33^{\circ} \mathrm{C}$ in the TS cell lines. It disappeared in TS cells $72 \mathrm{~h}$ following transfer to $39^{\circ} \mathrm{C}$. The majority (29) of the cell lines show binding of Dolichos biflorus lectin, suggesting distal tubule origin. Three cell lines show binding of Lotus tetragonolobus lectin or express aminopeptidase N, suggesting proximal tubule origin. Three cell lines were derived from a mixture of cysts and express features of both tubules. The PKD1 and PKD2 mRNA and protein were detected in all cells by RT-PCR and by immunocytochemistry. The majority of the cells tested also express the epidermal growth factor receptor, cystic fibrosis transmembrane conductance regulator, epithelial sodium channel, and renin. These new series of cyst-derived cell lines represent useful and readily available in vitro models for studying the cellular and molecular biology of ADPKD.

polycystic kidney disease; SV40

AUTOSOMAL DOMINANT POLYCYSTIC kidney disease (AD$\mathrm{PKD})$ is a common genetic disorder, which accounts for

Address for reprint requests and other correspondence: M. Loghman-Adham, 26 Huntington Road, Basking Ridge, NJ 07920 (Email: mloghman@att.net).
$8-10 \%$ of the end-stage renal disease population in the United States (7). ADPKD is caused by mutations in at least two separate genes. The PKD1 and PKD2 genes have been mapped to chromosomes 16p13.3 and 4q2123 , respectively $(19,35,41)$. Mutations in PKD1 account for $\sim 85 \%$ of the cases (41). Additional genes may be involved but have not been mapped. The gene products of PKD1 and PKD2, called polycystin-1 and polycystin-2, are large membrane-associated proteins whose function is not well known $(19,41)$. On the basis of their structure, they are likely involved in cell-cell and cell-matrix interactions $(2,41)$.

Polycystin-1 is expressed in fetal and neonatal kidneys, with much lower levels in the adult kidney (40). The highest expression is found in collecting ducts and distal nephrons (13). Polycystin-1 is also expressed in many cysts in adult ADPKD kidneys $(13,40)$. Polycystin-2 expression parallels that of polycystin-1, with primarily an intracellular localization (31). The highlevel expression of polycystin- 1 and -2 in cysts of adult ADPKD patients is difficult to reconcile with a loss-offunction mechanism. Expression of immunoreactive but nonfunctional protein is a likely possibility (31).

Cysts are the result of overgrowth of clonal tubule epithelial cells, reaching several centimeters in diameter (16). In ADPKD, cysts may originate from any nephron segment, including both the proximal and distal tubules/collecting ducts (3). They are composed of an epithelial monolayer attached to an abnormal and thickened basement membrane (43). Larger cysts develop their own capillary network, which provides nutrients to the cyst surface (4). The mechanism of cyst formation is not well understood but involves a combination of factors including transepithelial fluid secretion, tubular epithelial cell proliferation, and increased sensitivity to cAMP and to growth factors such as epidermal growth factor (EGF) (6). Recent studies showed that polycystin-2 can function as a nonspecific cation channel permeable to sodium and calcium $(8,15$, 18). Mutations in PKD2 (e.g., R742X) that result in a truncated protein lacking the $181 \mathrm{COOH}$-terminal amino acids result in partial translocation of polycys-

The costs of publication of this article were defrayed in part by the payment of page charges. The article must therefore be hereby marked "advertisement" in accordance with 18 U.S.C. Section 1734 solely to indicate this fact. 
tin-2 to the plasma membrane, altered $\mathrm{Ca}^{2+}$ permeability, and decreased sensitivity of the channel to intracellular $\mathrm{Ca}^{2+}$ concentrations $(15,39)$. Binding between polycystin- 1 and polycystin- 2 is also necessary for channel function (18).

Studies of the mechanisms of cyst formation and of genotype-phenotype correlations have been hampered by difficulties in obtaining ADPKD kidney specimens and by the lack of available and useful cyst-derived cell lines. Several investigators have used cyst-derived cells in primary culture $(28,29,43)$. These cells maintain many features of the cysts of origin and have been used to describe the properties of cyst epithelium. Unfortunately, primary cultures of cyst-derived cells cannot be maintained beyond three passages, necessitating frequent harvest of cells from nephrectomy specimens. The short life span of cyst-derived cells in primary culture precludes repeated studies on the same cell isolate. Furthermore, most investigators have isolated cells from several cysts pooled and digested together $(28,43)$. In prior studies, the tubule origin of cyst-derived cells has not usually been identified, making some of the results difficult to interpret. For example, Wilson et al. (43) reported reduced adenylate cyclase activity in response to parathyroid hormone (PTH) and AVP in cultured cyst-derived cells compared with cultured proximal and distal tubule cells, regardless of the location of the cysts within the renal cortex. They correctly noted that superficial cysts are not necessarily derived from proximal tubules and vice versa (43). To ensure that cysts of both proximal and distal tubule origin are obtained, one must dissect multiple individual cysts, isolate cells for culture, and then identify the desired cells with specific tubule markers.

We describe the isolation and subsequent immortalization of over 30 epithelial cells from individual cysts of 11 ADPKD kidneys. Twenty-one of the 23 cell isolates (29 cell lines) obtained from individual cysts have characteristic features of distal tubules with two cell isolates (9-7 and 9-12) showing features of proximal tubules. Four cell isolates [wild-type (WT) 1-2, WT 3-2, temperature sensitive (TS) 7-0, and WT/TS 17-0] were derived from a mixture of several cysts and were not subcloned. They are presumably derived from cysts of both proximal and distal tubule origin. However, based on lectin-binding properties and positive renin immunostaining (a feature of distal cysts), these cell mixtures are mainly of distal tubule origin. Some of the cells have been maintained in culture for over 50 passages without any phenotypic changes. The major characteristics of the cell lines are summarized in Table 1.

\section{METHODS}

Culture of cyst-derived cells. We initially isolated cells from cysts obtained from three polycystic kidneys, using a collagenase digestion method, previously described by other investigators $(29,41,43)$. The yield from this method was low, requiring several cysts to be pooled and digested together. Therefore, this method proved unsuitable for isolation of cells from single cysts. The cell isolates numbered 1-2, 3-2, and 7-0 were obtained by this method (Table 1). For subsequent kidneys, we used a trypsin/EDTA digestion method similar to that described by McAteer et al. (29) to release cells from cyst walls (Fig. 1). A total of 11 polycystic kidneys was used for this study. Because there was no difference in the characteristics of the cells cultured by these two methods, the data are combined. Briefly, cyst tops were excised, washed extensively in PBS, and incubated with $1 \times$ trypsin/EDTA at $37^{\circ} \mathrm{C}$ for 15-20 min. Each cyst was processed separately. The tubes containing the cyst fragments were vortexed vigorously every 5 min. Thereafter, ice-cold HBSS containing 10\% FBS was added to inactivate trypsin. The cells were further released from the fibrous cyst wall by trituration, washed twice with HBSS, then centrifuged and resuspended in fresh culture medium, and seeded on Pimaria culture plates. To allow attachment, the cells were grown for 24-48 h in DMEM containing $10 \%$ FBS. Thereafter, the medium was changed to a serum-free or to a low-serum (2\% FBS) medium, consisting of a 1:1 mixture of DMEM:Ham's F-12, supplemented with 5 $\mu \mathrm{g} / \mathrm{ml}$ insulin, $5 \mu \mathrm{g} / \mathrm{ml}$ transferrin, $5 \mathrm{ng} / \mathrm{ml}$ selenium, 36 $\mathrm{ng} / \mathrm{ml}\left(10^{-7} \mathrm{M}\right)$ hydrocortisone, $10^{-8} \mathrm{M}$ triiodothyronine, 10 $\mathrm{ng} / \mathrm{ml} \mathrm{EGF}$, and $50 \mathrm{ng} / \mathrm{ml} \mathrm{PGE}_{1}$, as well as $100 \mathrm{U} / \mathrm{ml}$ penicillin, and $100 \mu \mathrm{g} / \mathrm{ml}$ streptomycin, as described by Detrisac et al. (10). Except for higher hydrocortisone concentrations and the addition of EGF, the medium used is similar in composition to the K1 medium described by Taub et al. (34). The cells were grown at $37^{\circ} \mathrm{C}$ in a humidified incubator in $5 \%$ $\mathrm{CO}_{2}-95 \%$ air. The culture medium was changed every 2-3 days until confluency was reached. The cells were propagated by releasing them with $0.05 \%$ trypsin/ $0.53 \mathrm{mM}$ EDTA and were seeded on collagen I-coated culture dishes. Aliquots were frozen and stored in liquid nitrogen. The cells could be propagated for three passages, after which they became senescent and stopped dividing. They were, therefore, transformed and immortalized as described below.

Recombinant adeno-simian virus 40 viruses. Recombinant adeno-simian virus (SV)40 viruses were used to transform primary cultures of cyst-derived and control kidney epithelial cells. These viruses contain an origin-defective (ori ${ }^{-}$) SV40 DNA cloned into the adenovirus vector in place of early regions $1 \mathrm{a}$ and $1 \mathrm{~b}(38)$. Due to the removal of early region 1 , the adenovirus vector has no transforming activity and thus does not interfere with SV40-induced transformation (38). This ori ${ }^{-}$chimeric adeno-SV40 virus results in much higher efficiency of transformation compared with WT SV40 virus or to ori $^{-}$SV40 virus. Furthermore, because the SV40 portion lacks the origin or replication, viral replication does not occur within the cells (38). Two chimeric adeno-ori ${ }^{-}-\mathrm{SV} 40$ viruses were used containing either the WT or TS A209 SV40 that carries a point mutation at position 209 in the early region $(25,38)$. They were obtained from Dr. Janice Chou, National Institutes of Health. In this system, the chimeric virus attaches to the cell via the adenovirus receptor and allows intracellular introduction of the SV40, followed by integration of the SV40 DNA into the cell genome (1). The adenovirus acts as a vehicle and not as the transforming agent. Because it lacks the early region 1, the adenovirus does not replicate inside the cells $(32,38)$. The recombinant adenoSV40 viruses used in this study have been used previously to transform and immortalize human fibroblasts and human placental cells $(25,38)$.

Development of immortalized cells. The cells were seeded on 100-mm collagen-coated culture dishes and grown in serum-free hormone-supplemented medium until 50\% confluent. They were transformed with recombinant ori ${ }^{-}$adenoSV40 viruses as detailed above. The viral supernatants were 
Table 1. Major characteristics of ADPKD cyst-derived cell lines

\begin{tabular}{|c|c|c|c|c|c|c|c|c|c|c|c|}
\hline $\begin{array}{l}\text { Cell } \\
\text { Line }\end{array}$ & $\begin{array}{l}\text { SV40 } \\
\text { Type }\end{array}$ & $\begin{array}{c}\text { Single or } \\
\text { Pooled }\end{array}$ & $\begin{array}{l}\text { Sex of } \\
\text { Donor }\end{array}$ & $\begin{array}{l}\text { Tubule } \\
\text { Origin }\end{array}$ & $\begin{array}{l}\text { Highest } \\
\text { Passage }\end{array}$ & EGF-R & $\mathrm{ENaC}$ & AGT & Renin & PKD1 & PKD2 \\
\hline $1-2$ & WT & Pooled & M & NK & 8 & $+(\mathrm{I})$ & & & $+(\mathrm{R})$ & $+(\mathrm{R})$ & $+(\mathrm{R})$ \\
\hline $3-2$ & WT & Pooled & $\mathrm{M}$ & NK & 15 & & & $+(\mathrm{R})$ & $+(\mathrm{R})$ & $+(\mathrm{R})$ & \\
\hline $7-0$ & TS & Pooled & $\mathrm{F}$ & NK & 21 & $+(\mathrm{I})$ & $+(\mathrm{R})$ & $+(\mathrm{R})$ & $+(\mathrm{R})$ & $+(\mathrm{R})$ & $+(\mathrm{R})$ \\
\hline $9-1$ & WT & Single & $\mathrm{F}$ & Distal & 3 & & $-(\mathrm{R})$ & $-(\mathrm{R})$ & $+(\mathrm{R})$ & $+(\mathrm{R})$ & $+(\mathrm{R})$ \\
\hline $9-2$ & WT & Single & $\mathrm{F}$ & Distal & 8 & $-(\mathrm{I})$ & & $-(\mathrm{R})$ & $+(\mathrm{R})$ & $+(\mathrm{R})$ & $+(\mathrm{R})$ \\
\hline $9-3$ & WT & Single & $\mathrm{F}$ & Distal & 9 & $+(\mathrm{I})$ & & $-(\mathrm{R})$ & $+(\mathrm{R})$ & $+(\mathrm{R})$ & $+(\mathrm{R})$ \\
\hline $9-7$ & TS, WT & Single & $\mathrm{F}$ & Prox & 42 & $+(\mathrm{I})$ & & $+(\mathrm{I})$ & $-(\mathrm{I})$ & $+(\mathrm{I})$ & $+(\mathrm{I})$ \\
\hline $9-9$ & WT & Single & $\mathrm{F}$ & Distal & 14 & $+(\mathrm{I})$ & & $-(\mathrm{I})$ & $+(\mathrm{I})$ & $+(\mathrm{I})$ & $+(\mathrm{I})$ \\
\hline $9-12-\mathrm{D}$ & WT & Single & $\mathrm{F}$ & Distal & 35 & $+(\mathrm{I}, \mathrm{R})$ & $+(\mathrm{R})$ & & & & \\
\hline $9-12-\mathrm{L}$ & WT & Single & $\mathrm{F}$ & Prox & 36 & $+(\mathrm{I}, \mathrm{R})$ & $+(\mathrm{R})$ & & & & \\
\hline $10-2$ & WT, TS & Single & $\mathrm{F}$ & Distal & 4 & & & & & & \\
\hline $10-3$ & WT, TS & Single & $\mathrm{F}$ & Distal & 5 & & & & & & \\
\hline $10-4$ & WT & Single & $\mathrm{F}$ & Distal & 5 & & & & & & \\
\hline $10-7$ & WT, TS & Single & $\mathrm{F}$ & Distal & 20 & $-(\mathrm{I})$ & & $-(\mathrm{R})$ & $+(\mathrm{R})$ & $+(\mathrm{I}, \mathrm{R})$ & $+(\mathrm{I}, \mathrm{R})$ \\
\hline $11-3$ & WT, TS & Single & $\mathrm{F}$ & Distal & 12 & $+(\mathrm{I})$ & $+(\mathrm{R})$ & $-(\mathrm{R})$ & $+(\mathrm{R})$ & & \\
\hline $11-6$ & WT, TS & Single & $\mathrm{F}$ & Distal & 13 & $+(\mathrm{I})$ & $+(\mathrm{R})$ & $-(\mathrm{R})$ & $+(\mathrm{I}, \mathrm{R})$ & & \\
\hline $11-7$ & WT, TS & Single & $\mathrm{F}$ & Distal & 19 & $+(\mathrm{I}) ?$ & $+(\mathrm{R})$ & $-(\mathrm{R})$ & $+(\mathrm{I}, \mathrm{R})$ & & \\
\hline $11-12$ & WT & Single & $\mathrm{F}$ & Distal & 18 & $+(\mathrm{I})$ & & & & & \\
\hline $12-1$ & $\mathrm{TS}$ & Single & M & Distal & 8 & & & & & & \\
\hline $13-1$ & TS & Single & $\mathrm{M}$ & Distal & 3 & & & & & & \\
\hline $13-3^{*}$ & TS & Pooled & $\mathrm{M}$ & Distal & 7 & & & & & & \\
\hline $14-2^{*}$ & WT, TS & Pooled & $\mathrm{F}$ & NK & 7 & $+(\mathrm{I})$ & & & & & \\
\hline $13-6$ & TS & Single & $\mathrm{M}$ & Distal & 6 & & & & & & \\
\hline $17-8$ & WT, TS & Single & $\mathrm{F}$ & Distal & 7 & & & & & & \\
\hline $17-9$ & WT, TS & Single & $\mathrm{F}$ & Distal & 7 & & & & & & \\
\hline $17-0 *$ & WT, TS & Pooled & $\mathrm{F}$ & NK & 3 & & & & & & \\
\hline $18-3$ & TS & Single & M & NK & 5 & & & $+(\mathrm{I})$ & & & \\
\hline $18-5$ & $\mathrm{TS}$ & Single & $\mathrm{M}$ & NK & 7 & & & $+(\mathrm{I})$ & & & \\
\hline $19-1$ & TS & Single & $\mathrm{M}$ & Distal & 6 & & & & & & \\
\hline $19-9$ & TS & Single & M & Distal & 9 & & & $+(\mathrm{I})$ & & & \\
\hline RCTEC & WT & N/A & NK & Prox & 47 & $+(\mathrm{R})$ & & $+(\mathrm{I})$ & & $+(\mathrm{I})$ & $+(\mathrm{I})$ \\
\hline RCTEC & WT, TS & N/A & NK & Distal & 47 & & & $-(\mathrm{I})$ & $-(\mathrm{I})$ & $+(\mathrm{I})$ & $+(\mathrm{I})$ \\
\hline
\end{tabular}

The cells were obtained from cysts of 11 autosomal dominant polycystic kidney disease (ADPKD) kidneys. In the first column, the first number denotes the kidney number and the second the cyst number. The second column identifies the type of simian virus (SV) 40 virus used for transformation. WT, cells immortalized with wild-type adeno-SV40 virus; TS, cells immortalized with temperature-sensitive virus. For example, cells numbered 10-2, 10-3, 10-4, and 10-7 were obtained from 4 individual cysts of kidney no. 10 and subsequently infected with either WT or TS viruses. Cells were assigned proximal (Prox) or distal tubule origin if they bound FITC-labeled Dolichos biflorus or Lotus tetragonolobus agglutinin lectin, respectively. Proximal tubule origin was further confirmed by immunocytochemistry, showing the presence of aminopeptidase N (CD13) on cell membranes. EGF-R, epidermal growth factor receptor; ENaC, epithelial sodium channel; AGT, angiotensinogen; I, demonstration by immunocytochemistry; R, demonstration by RT-PCR; RCTEC, renal cortical tubule epithelial cells; NK, tubule origin not known. * Cell isolates obtained from deep portions of ADPKD kidneys. Cell lines 1-2, 3-2, and 7-0 were derived from a mixture of cysts pooled and processed together. RCTEC cell lines were obtained from primary cultures of normal human renal cortical tubule cells. WT RCTEC has been subcloned into proximal and distal tubule cell lines.

obtained from infected HEK293 cells and kept at $-80^{\circ} \mathrm{C}$ until use. Between 1.5 and $2.0 \mathrm{ml}$ of viral supernatant $\left(\sim 10^{8}\right.$ plaque-forming units/ml) were used per plate. Both WT and TS viruses were used. The cells were incubated with the virus at $37^{\circ} \mathrm{C}$ for $60 \mathrm{~min}$, and then the supernatant was aspirated and replaced with fresh culture medium. Thereafter, the medium was changed every $2-3$ days. The cells infected with the WT virus were grown at $37^{\circ} \mathrm{C}$, and those infected with the TS virus were grown at $33^{\circ} \mathrm{C}$. After viral infection, the majority of the cells became dysmorphic, taking on the appearance of "ghost" cells. A few distinct colonies of normal-appearing cells remained, which became subconfluent over a period of 5-6 wk. These surviving cells were subcultured into additional collagen-coated plates and maintained in hormone-supplemented medium with $2 \%$ FBS until passage 6 . Thereafter, DMEM with $10 \%$ FBS was used. With the use of this method, we did not observe any fibroblast contamination.

In addition to cyst-derived cells, we immortalized normal human renal cortical tubule epithelial cells (RCTEC) to be used as the control for our cyst-derived cell lines. The cells were purchased at passage 1 from Clonetics (Walkersville, MD). They were immortalized using the same adeno-SV40 viruses and culture conditions used to immortalize the cystderived cells. The culture medium used for RCTEC was identical to that used for cyst-derived cells, except that it did not contain EGF. Although the primary cultures of RCTEC contained a mixture of $\sim 20 \%$ proximal and $80 \%$ distal tubule-derived cells, continued culture with the above medium resulted in the preferential growth of cells of distal tubule origin as evidenced by Dolichos biflorus (DBA) lectin staining. These cells were further subcloned by limited dilution to obtain pure populations of proximal and distal tubule cell lines that were identified by their lectin-binding characteristics. Accordingly, the distal tubule cell line has been named RCTEC-DBA and the proximal tubule cell line named RCTEC-Lotus tetragonolobus agglutinin (LTA).

Immunocytochemistry of cell monolayers. The WT cells were seeded on collagen-coated coverslips and grown at $37^{\circ} \mathrm{C}$ for 24 to $48 \mathrm{~h}$ before study. The TS cells were initially grown at $33^{\circ} \mathrm{C}$, then transferred to 37 or $39^{\circ} \mathrm{C}$ for $72 \mathrm{~h}$ before study. For the majority of studies, the two-step immunofluorescence 


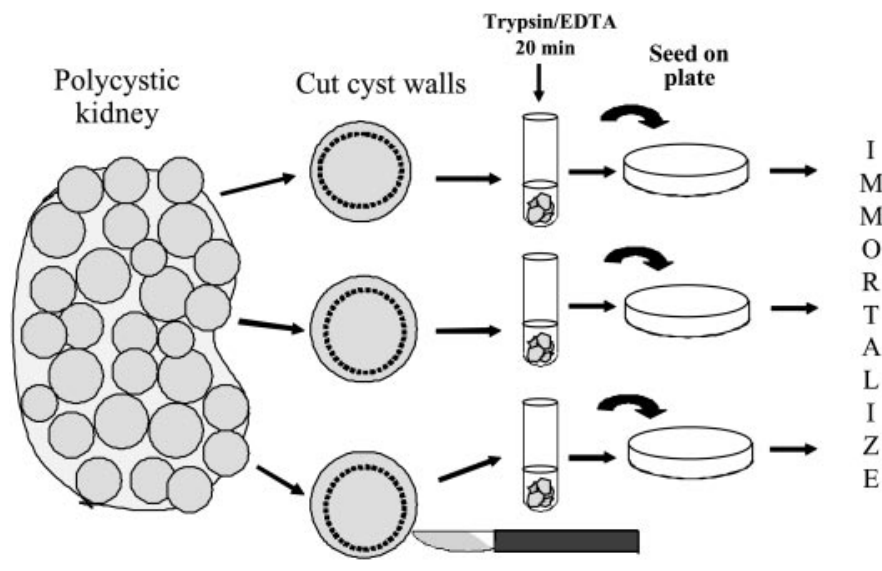

Fig. 1. Schematic diagram of isolation of epithelial cells from polycystic kidneys. Several cyst tops were individually dissected with a scalpel blade. Each cyst cutout was rinsed extensively in ice-cold PBS and then placed in a separate tube containing $1 \times$ trypsin/ EDTA. The cysts were incubated for $20 \mathrm{~min}$ at $37^{\circ} \mathrm{C}$ and vortexed vigorously every $5 \mathrm{~min}$ to allow separation of cells from the cyst wall. The cyst walls stripped of cells were removed and the cells were washed twice in Hanks' buffered salt solution with $10 \%$ fetal bovine serum. The final pellet was resuspended in serum-deficient hormone-supplemented medium and seeded on Primaria culture plates. The cells were transformed at passage 1 or 2 when $30-50 \%$ confluence was reached.

method was used. The cells were washed three times with PBS and then fixed for 15 min with $4 \%$ paraformaldehyde in PBS, followed by three washes with PBS. The cells were permeabilized for $5 \mathrm{~min}$ at room temperature with $0.5 \%$ Triton X-100 in PBS, washed twice with PBS, and blocked with $0.5 \% \mathrm{BSA}$ in PBS for $20 \mathrm{~min}$. After incubation with primary antibodies for $1 \mathrm{~h}$ at room temperature, the cells were washed three times with PBS followed by incubation with FITC-labeled secondary antibodies (anti-mouse or antirabbit IgG, used at 1:100 to 1:200 dilution) for $30 \mathrm{~min}$ in the dark. The dilutions for the primary antibodies are indicated in Reagents and supplies. For lectin-binding studies, FITClabeled LTA, Arachis hypogaea (PNA), or DBA lectins were added directly to the cells at 1:50-1:100 dilution and incubated for $30 \mathrm{~min}$ at room temperature. LTA is a marker of proximal tubules, and PNA and DBA are markers of distal and collecting tubules. The cells were washed with PBS and mounted on slides, using FluoroGuard antifade mounting solution (Bio-Rad, Hercules, CA). The slides were viewed with a Zeiss Axioplan microscope equipped with epifluorescence and photographed using Kodak Elitechrome 400 film at either 8- or 15-s exposure.

In some studies, immunocytochemistry was performed with the $\mathrm{ABC}$ method, using a commercial kit (Vectastain Elite kit, Vector Laboratories, Burlingame, CA). The cells were washed three times with PBS and then blocked with normal horse serum for $20 \mathrm{~min}$ at room temperature, followed by the addition of the primary antibodies. The cells were incubated overnight at $4^{\circ} \mathrm{C}$ and then washed three times with PBS/0.1\% Tween 20, followed by the addition of the second (biotinylated) antibody and incubated for $30 \mathrm{~min}$ at room temperature. The cells were washed three times with PBS followed by the addition of one drop of the ABC reagent and incubated at room temperature for $30 \mathrm{~min}$. They were washed three times with PBS, followed by the addition of peroxidase substrate for 6-10 $\mathrm{min}$, then rinsed in distilled water, counterstained with hematoxylin, washed extensively in running water, and mounted. The slides were viewed with a Zeiss Axioplan microscope and photographed with Kodak Ektachrome 64T film.

Electrical resistance measurements. The cells were grown at high density on $0.45-\mu \mathrm{m}$ pore size collagen I-coated translucent permeable filter inserts (Biocoat, Collaborative Biomedical Products, Bedford, MA) and placed inside 12-well plates. When confluency was reached, electrical resistance was measured across the filter, using a Voltohmeter (World Precision Instruments, Sarasota, FL). The resistance across empty filters was subtracted from the resistance across cell monolayers, and the value obtained was corrected for the surface area of the filter and expressed as ohms per centimeter squared.

Electron microscopy. The cells were grown on filters as above and then fixed with $2.5 \%$ glutaraldehyde/1\% paraformaldehyde in cacodylate buffer ( $\mathrm{pH} 7.4$ ). They were postfixed with $1 \%$ osmium tetroxide in cacodylate buffer, dehydrated with a graded series of alcohols, and embedded in epoxy resin. Cross sections of the monolayers were cut with a diamond knife. The thin sections were counterstained with uranyl acetate and lead citrate. The specimens were observed and photographed with a JEOL 100S transmission electron microscope (JEOL, Tokyo, Japan).

$R N A$ isolation and RT-PCR. The cells were grown to confluence in $100-\mathrm{mm}$ culture plates or $75-\mathrm{cm}^{2}$ flasks, then scraped, washed in PBS, and centrifuged. The cell pellet was snap-frozen in dry-ice ethanol, and stored at $-70^{\circ} \mathrm{C}$ until used for RNA preparation. Total RNA was prepared, using commercial kits (either RNeasy, Qiagen, Valencia, CA or TRIzol Reagent, Invitrogen, Carlsbad, CA). mRNA for various genes was detected by reverse transcription of the RNA to obtain the complementary DNA (cDNA), followed by polymerase chain reaction (RT-PCR), using a Commercial kit (Access RT-PCR, Promega, Madison, WI). Two different pairs of oligonucleotide primers were designed, corresponding to the $5^{\prime}$ - and $3^{\prime}$-regions of the genes (Table 2). The primers were designed to span one or more exon-intron junctions to allow the distinction of products amplified from genomic DNA. Parallel tubes were used in which the reverse transcriptase was omitted (designated $-\mathrm{RT}$ ), which were then subjected to the same steps as those containing this enzyme (designated + RT). PCR amplifications were performed for 30-35 cycles under fairly stringent conditions, using an MJ Research PTC-200 Thermocycler. Each cycle consisted of denaturation at $94^{\circ} \mathrm{C}$ for $30 \mathrm{~s}$, annealing at $58^{\circ} \mathrm{C}$ for $1 \mathrm{~min}$, and extension at $72^{\circ} \mathrm{C}$ for $1 \mathrm{~min}$. Each experiment was carried out at least twice. In all experiments, one or more water blanks were used to verify the lack of illegitimate amplification. RTPCR reactions were repeated in parallel with the same amount of RNA, using primers for the $\beta$-actin gene, to check for the quality of the reaction and to allow for evaluation of the amount of RNA used in each reaction. In some experiments, GAPDH or $\alpha$-tubulin primers were used instead of $\beta$-actin. The reaction products were size fractionated on $1.5 \%$ agarose gels with ethidium bromide and photographed.

For detection of SV40 DNA integration into the cell genome, DNA was isolated, using a commercial kit (QIAmp DNA mini kit, Qiagen). SV40 DNA was amplified by PCR, using specific oligonucleotide primers (Table 2).

Gel electrophoresis and Western blotting. Cells grown on collagen-coated 60- or 100-mm culture dishes were washed twice with ice-cold PBS, scraped, and collected by centrifugation. The pellet was homogenized in a small volume of lysis buffer (50 mM NaCl, $50 \mathrm{mM}$ Tris $\cdot \mathrm{HCl}, \mathrm{pH}$ 8.0, 0.2\% NP-40, $0.5 \mathrm{mM}$ PMSF) and incubated on ice for $60 \mathrm{~min}$, followed by two freeze-thaw cycles. After centrifugation at $10,000 \mathrm{~g}$ for 10 
Table 2. Primers used in PCR amplification

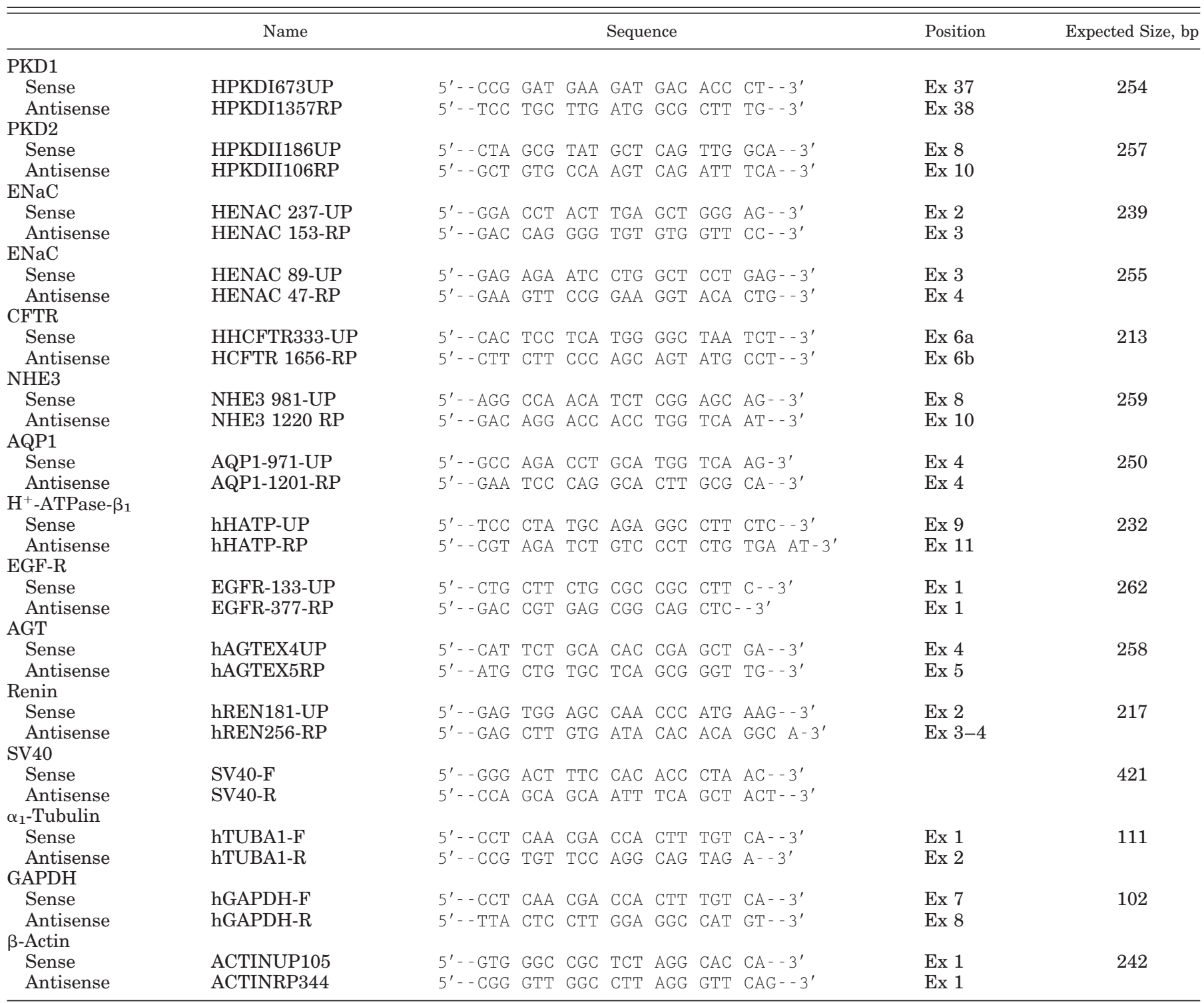

CFTR, cystic fibrosis transmembrane conductance regulator; NHE3, $\mathrm{Na}^{+}-\mathrm{H}^{+}$exchanger 3; AQP1, aquaporin-1; Ex, exon.

min, the supernatant was transferred to new tubes and frozen at $-70^{\circ} \mathrm{C}$.

SDS-PAGE was performed according to Laemmli (23). After separation, protein bands were electrophoretically transferred to polyvinylidene difluoride membranes (Immobilon-P) according to Towbin et al. (37). Nonspecific sites were blocked by incubating the membranes for at least $2 \mathrm{~h}$ at room temperature in a blocking buffer consisting of Trisbuffered saline, $\mathrm{pH} 7.4,0.2 \%$ Tween 20 (TBS-T) and 3\% BSA. After two washes in TBS-T, a 1:500 to 1:1,000 dilution of the primary antibody (in blocking buffer) was added to the membranes, followed by incubation at room temperature for $2 \mathrm{~h}$. After three washes in TBS-T, the second antibody was added (1:20,000 to $1: 40,000$ dilution of a horseradish peroxidaseconjugated anti-mouse or anti-rabbit IgG), and the membranes were incubated for $2 \mathrm{~h}$ at room temperature. After four washes in TBS-T, the protein bands were visualized, using the SuperSignal West Pico chemiluminescence detection method (BioRad Laboratories). Membranes were briefly exposed to radiographic film for a permanent record.
Measurement of cAMP. Cells grown in 12-well collagencoated plates were transferred to serum-free DMEM for $15 \mathrm{~h}$ before the experiments. They were preincubated for $1 \mathrm{~h}$ with serum-free DMEM containing 0.5 mM 3-isobutyl-1 methylxanthine (IBMX), a phosphodiesterase inhibitor, followed by the addition of parathyroid hormone $\left(10^{-6} \mathrm{M}\right)$ or AVP $\left(10^{-6}\right.$ $\mathrm{M})$. In some experiments, forskolin $\left(10^{-5} \mathrm{M}\right)$ was used as a positive control. After 10 -min incubation at $37^{\circ} \mathrm{C}$, the media were aspirated and the cells were washed three times with ice-cold PBS. Thereafter, $1 \mathrm{ml}$ of a 100:1 mixture of ethanol/1 $\mathrm{N} \mathrm{HCl}$ was added to each well and the cells were incubated overnight at $4^{\circ} \mathrm{C}$. After extraction, the ethanol was evaporated and the extract was resuspended in $0.25 \mathrm{ml}$ of ice-cold Tris-buffered saline ( $\mathrm{pH}$ 7.4) containing $4 \mathrm{mM}$ EDTA and frozen at $-20^{\circ} \mathrm{C}$ until assayed. cAMP was measured by radioimmunoassay, using a commercial kit (Biotrak, Amersham, Arlington Heights, IL).

Each experiment was repeated at least two more times. Where appropriate, statistical analysis was performed by 
Student's $t$-test for group comparisons. A $P$ value of $\leq 0.05$ was considered significant.

Reagents and supplies. Tissue culture media and FBS were purchased from GIBCO Invitrogen (Carlsbad, CA). Rat tail collagen I (no. 354236) was purchased from Becton Dickinson (Bedford, MA). Monoclonal antibody against pan-cytokeratin was purchased from Sigma (St. Louis, MO) and used at 1:100 dilution for immunofluorescence studies and at 1:250 dilution with the $\mathrm{ABC}$ method. Monoclonal antibody against vimentin was purchased from Boehringer/Roche (Indianapolis, IN) and used at 1:100 dilution for immunofluorescence studies and at 1:250 dilution with the ABC method. Monoclonal antibodies against aminopeptidase N (CD13) and the SV40 large T antigen were purchased from Santa Cruz Biotechnology (Santa Cruz, CA) and used at 1:250 and 1:100 dilution, respectively. The rabbit polyclonal antibody against the extracellular region of polycystin-1 (mr-3) and rabbit polyclonal antibody against polycystin-2 were prepared in Dr. Jing Zhou's laboratory and have been previously described (14). Both were used at 1:250 dilution. FITC-labeled secondary antibodies were purchased from Pierce (Rockford, IL). FITC-labeled LTA, PNA, and DBA lectins were purchased from Sigma and used at 1:50 to 1:100 dilution. RNA and DNA isolation kits were purchased from Qiagen. RTPCR kit (Access RT-PCR) was purchased from Promega. Oligonucleotide primers were synthesized by GIBCO Invitrogen. Other reagents of highest purity grades were purchased from Sigma, Fisher, or other commercial suppliers.

\section{RESULTS}

Characteristics of ADPKD cells. The majority of the cells were transformed at the second passage after the initial seeding. After infection with the recombinant adeno-SV40 viruses, the cells divided rather slowly with continued presence of large ghost cells that were gradually replaced by healthy appearing cells over $5-8$ wk. The surviving cells were maintained in a hormonesupplemented medium containing $2 \%$ FBS to inhibit fibroblast growth. After passage 6, the medium was changed to DMEM with $10 \%$ FBS. The cells have been maintained in this medium for $8-42$ passages. From 30 cyst-derived cell isolates, we obtained a total of 41 transformed cell lines, 21 of which were transformed with WT SV40 viruses and 20 with TS SV40 viruses. Among these, 11 cell lines were successfully transformed with both WT and TS viruses. Additionally, SV40-transformed control proximal and distal renal tubule epithelial cells were obtained from a normal human renal cortical epithelial cell isolate (Table 1).

The cells immortalized with the WT virus (WT series) are continuously grown at $37^{\circ} \mathrm{C}$. Those immortalized with the TS virus (TS series) are maintained at $33^{\circ} \mathrm{C}$. To induce expression of a normal phenotype, the TS cells are transferred to 39 or $37^{\circ} \mathrm{C}$ for $72 \mathrm{~h}$ before the experiments. The TS cells remain viable for at least 7 days after transfer to the nonpermissive temperature (not shown).

When seeded on either uncoated or on collagen Icoated culture dishes, the cells grow as monolayers with contact inhibition, as evidenced by the observation of a plateau on growth curves. Their morphology varies from a polygonal or cobblestone appearance typical of epithelial cells to elongated or fusiform shapes and swirls (Fig. 2). In one cell isolate (14-2), we observed dome formation at the initial seeding but domes were not seen in cultures of immortalized cells (Fig. $2 B$ ). To determine the growth characteristics of the cells, representative samples from both WT and TS cyst-derived cells were seeded in 12-well multiwell plates at a density of 20,000 cells/well. Beginning on the third day after seeding, the cells in duplicate wells were trypsinized every $24 \mathrm{~h}$ and counted with a hemocytometer. The WT cells were maintained at $37^{\circ} \mathrm{C}$ for the duration of the study. The TS cells were seeded on two different 12-well plates and initially grown at $33^{\circ} \mathrm{C}$. Seventy-two hours after seeding, one plate was switched to $37^{\circ} \mathrm{C}$ and daily cell counts were continued from duplicate wells of each plate. The WT cells and TS cells grown at 37 and $33^{\circ} \mathrm{C}$, respectively, showed typical "S"-shaped growth curves with faster growth rate for WT cells (Fig. 3, $A$ and $B$ ). The doubling times estimated from the linear portion of the exponential phase of growth curves were $\sim 33 \mathrm{~h}$ for WT 9-7 cells grown at $37^{\circ} \mathrm{C}$ and $\sim 48 \mathrm{~h}$ for TS 9-7 cells grown at $33^{\circ} \mathrm{C}$. We also calculated the "growth rate" of the same cells using log-linear transformation of the growth data (Fig. 3, C and D). With the use of the values from log-linear transformations, the doubling times were $\sim 38 \mathrm{~h}$ for WT 9-7 cells and $\sim 64 \mathrm{~h}$ for TS 9-7 cells. In TS cells, cell division and growth rate slowed and ceased $\sim 96 \mathrm{~h}$ after transfer to $39^{\circ} \mathrm{C}$, coinciding with the disappearance of the large $\mathrm{T}$ antigen on Western blots. In general, growth rates were more a function of the growth temperature necessitated by the immortalizing SV40 virus used (faster for WT cells than for TS cells) than of the kidney or cyst from which the cells originated.

Previous studies showed increased life span and better differentiation when renal epithelial cells are grown on collagen or other extracellular matrix components $(10,26)$. We therefore used collagen I-coated plates and dishes for all subsequent experiments. Regardless of culture conditions (presence or absence of serum) and the type of substratum, the nontransformed cyst-derived cells could not be maintained in culture beyond three passages.

With the use of immunocytochemistry with a pancytokeratin antibody, we demonstrated the expression of cytokeratin by all the immortalized cells studied, confirming their epithelial origin (Fig. 4, $A$ and $C$ ). The cells also express vimentin, a component of cells of mesenchymal origin (Fig. $4, B$ and $D$ ). The significance of this finding is not clear, but it may be related to the undifferentiated nature of these cells (42). Other epithelial cells such as podocytes have also been shown to express vimentin (44).

Characterization of tubule origin of the cysts and cells. To determine the tubule origin of the cyst-derived cells, we used lectins that bind specifically to sugar moieties in proximal and distal tubules as well as antibodies to tubule-specific proteins. We used LTA and aminopeptidase $\mathrm{N}$ (CD13) as proximal tubule markers and DBA or PNA as distal tubule markers (18). Twenty-one of 30 transformed cell isolates corre- 

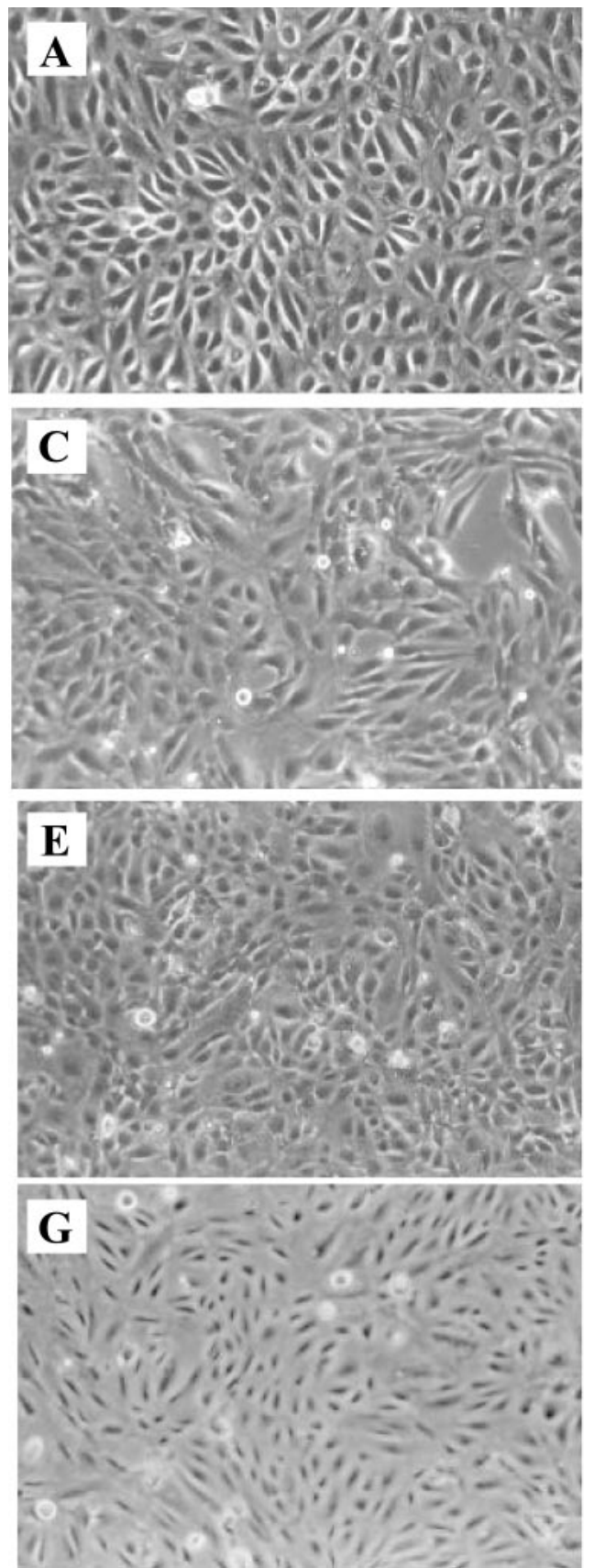
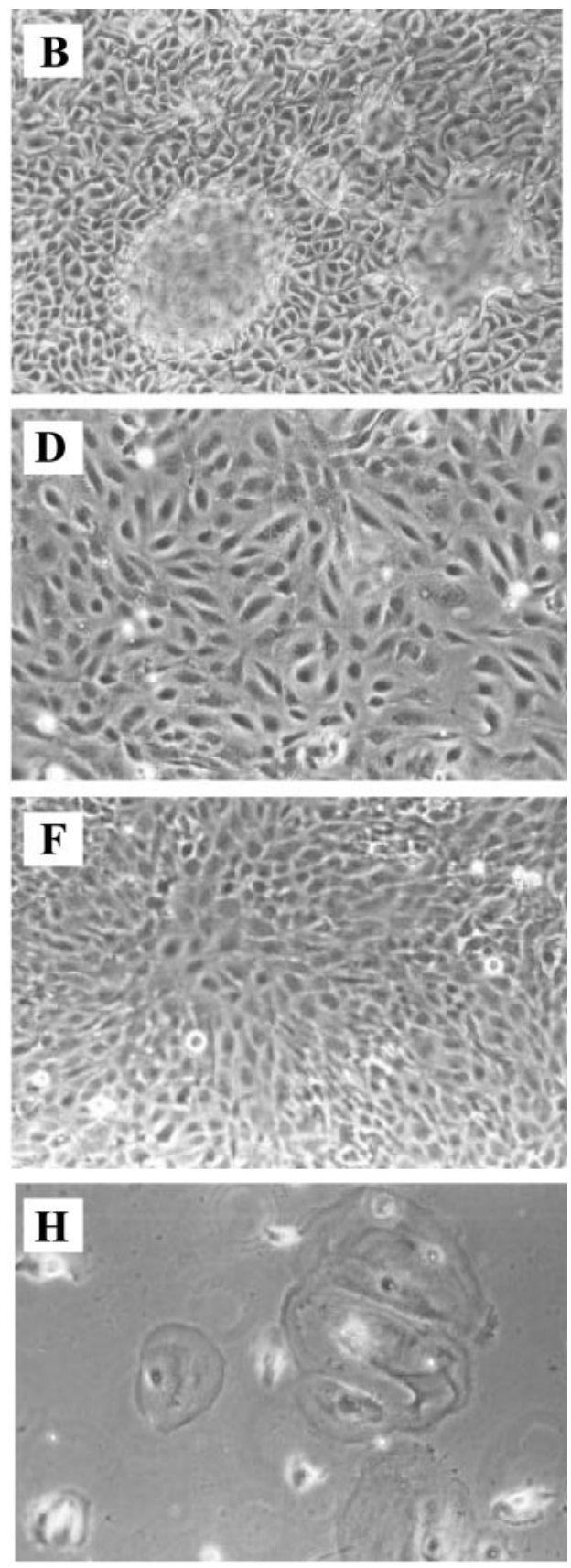

Fig. 2. Phase-contrast microscopy of immortalized cyst-derived cells. $A$ and $B$ : confluent monolayers of cyst-derived cells (14-4 and 14-2) in primary culture. $B$ : note dome formation. $C$ : confluent monolayer of an immortalized temperature-sensitive (TS) cell line (TS 9-7) derived from a cyst of proximal origin; $D$ : cell line (TS 11-7) derived from a cyst of distal origin, both grown at $33^{\circ} \mathrm{C}$. $E$ : confluent monolayer of an immortalized wild-type (WT) cell line (WT 9-7) from a cyst of proximal origin; $F$ : WT cell line (WT 10-7) derived from a cyst of distal origin. $G$ : confluent monolayer of control human renal distal tubule epithelial cell line (WT RCTEC). $H$ : recently transformed cyst-derived cells with multiple "ghost" cells. All cells were grown on collagen I-coated culture plates. Magnification $\times 100$. sponding to a total of $29 \mathrm{WT}$ and TS cell lines bound DBA or PNA lectins, suggesting distal tubule origin of the cysts (Table 1). Two transformed cell isolates corresponding to three WT and TS cell lines (WT 9-7, TS 9-7, and WT 9-12) bound LTA lectin or showed positive staining with CD13 antibody, suggesting proximal tubule origin of the cyst (Table 1 and Fig. 5). Five cell isolates (1-2, 3-2, 7-0, 13-3, 14-2, and 17-0) represent mixtures of DBA- and LTA-positive cells and two isolates (18-3 and 18-5) derived from single cysts could not be classified due to conflicting lectin-binding results. These two cell lines express angiotensinogen, a feature of proximal tubules (Table 1). Lectin-binding characteristics did not change in those cells that were studied as primary cultures before immortalization and again after they were immortalized (Fig. 5, $G$ and $H$ ). On the basis of these criteria, we have been successful in isolating cyst-derived cells representing cysts of both proximal and distal tubule origin.

We also measured the transepithelial electrical resistance across cells grown on collagen-coated permeable filter inserts. In four cell isolates (9-5, 9-6, 10-7, 11-6) in primary culture, the mean transepithelial electrical resistance measured in duplicate filters was $128 \pm 7 \Omega / \mathrm{cm}^{2}(n=4)$, which is comparable to the electrical resistance measured in leaky epithelia such as proximal tubules. Other cell isolates had significantly higher electrical resistances $[2,204.3 ; 1,027.5$; 
A

Fig. 3. Growth curves of WT and TS immortalized cyst-derived cells. $A$ : growth curve of a representative WT cell line (WT 9-7) at $37^{\circ} \mathrm{C}$, showing a typical S-shaped curve with an initial lag time followed by exponential growth, then slower growth, as the cells become confluent. $B$ : growth curve of a representative TS cell line (TS 9-7) under permissive and nonpermissive conditions. Cells were grown at $33^{\circ} \mathrm{C}$, and then one-half were transferred to $37^{\circ} \mathrm{C}$ (arrow) and the other one-half were kept at $33^{\circ} \mathrm{C}$. The TS cells continue to divide when maintained at $33^{\circ} \mathrm{C}$. In TS cells transferred to $37^{\circ} \mathrm{C}$, cell growth slows $48-72 \mathrm{~h}$, following transfer to the nonpermissive temperature. The cells cease to grow and die when left 7 days or more at this temperature. $C$ and $D$ : same data as in $A$ and $B$ plotted on a log scale. The slopes of the lines correspond to growth rates of the cells.

C
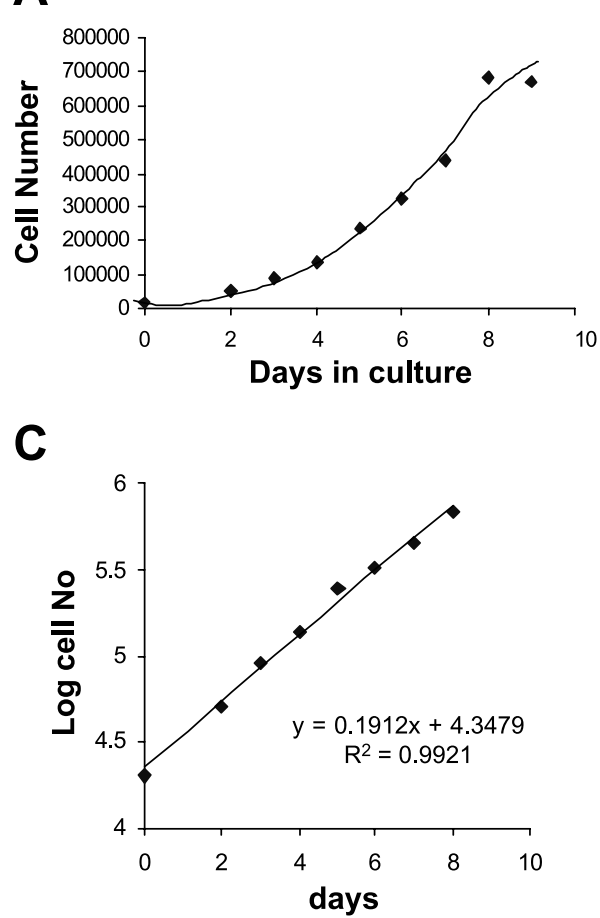

B

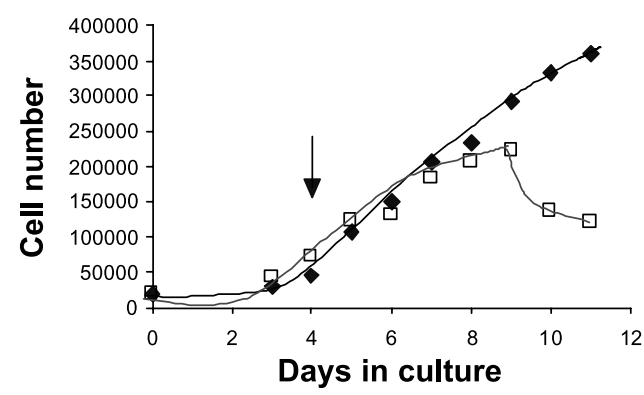

D

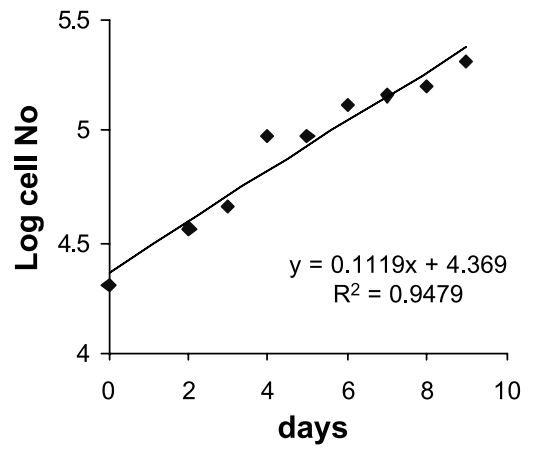

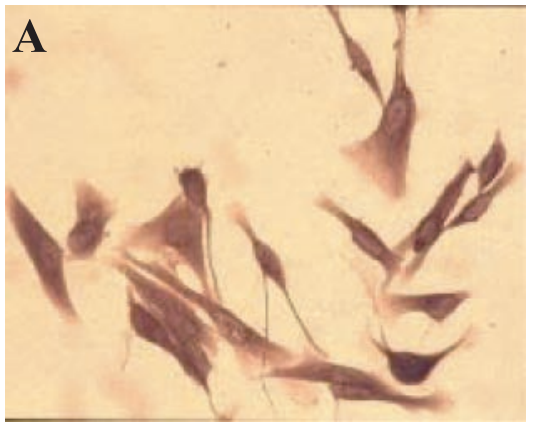
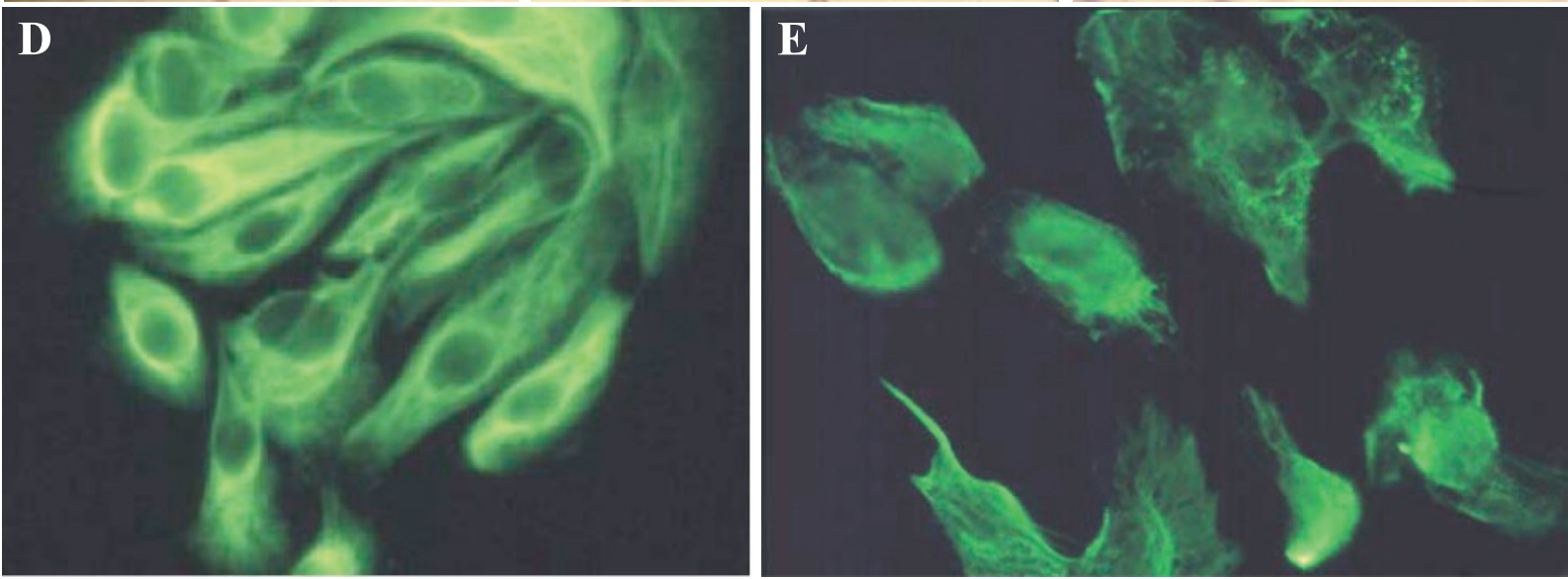

Fig. 4. Expression of cytokeratin and vimentin in cyst-derived cells. The cells were seeded on collagen I-coated coverslips and used for immunocytochemistry using either the ABC method $(A-C)$ or FITC-labeled second antibody $(D$ and $E)$. Strong cytokeratin staining $(A$ and $D$ ) confirms epithelial origin of the cells. The cells also express vimentin $(B$ and $E$ ), consistent with loss of differentiation. $C$ : cells incubated with preimmune IgG show no staining. The results are representative of 3 experiments in different cells. 

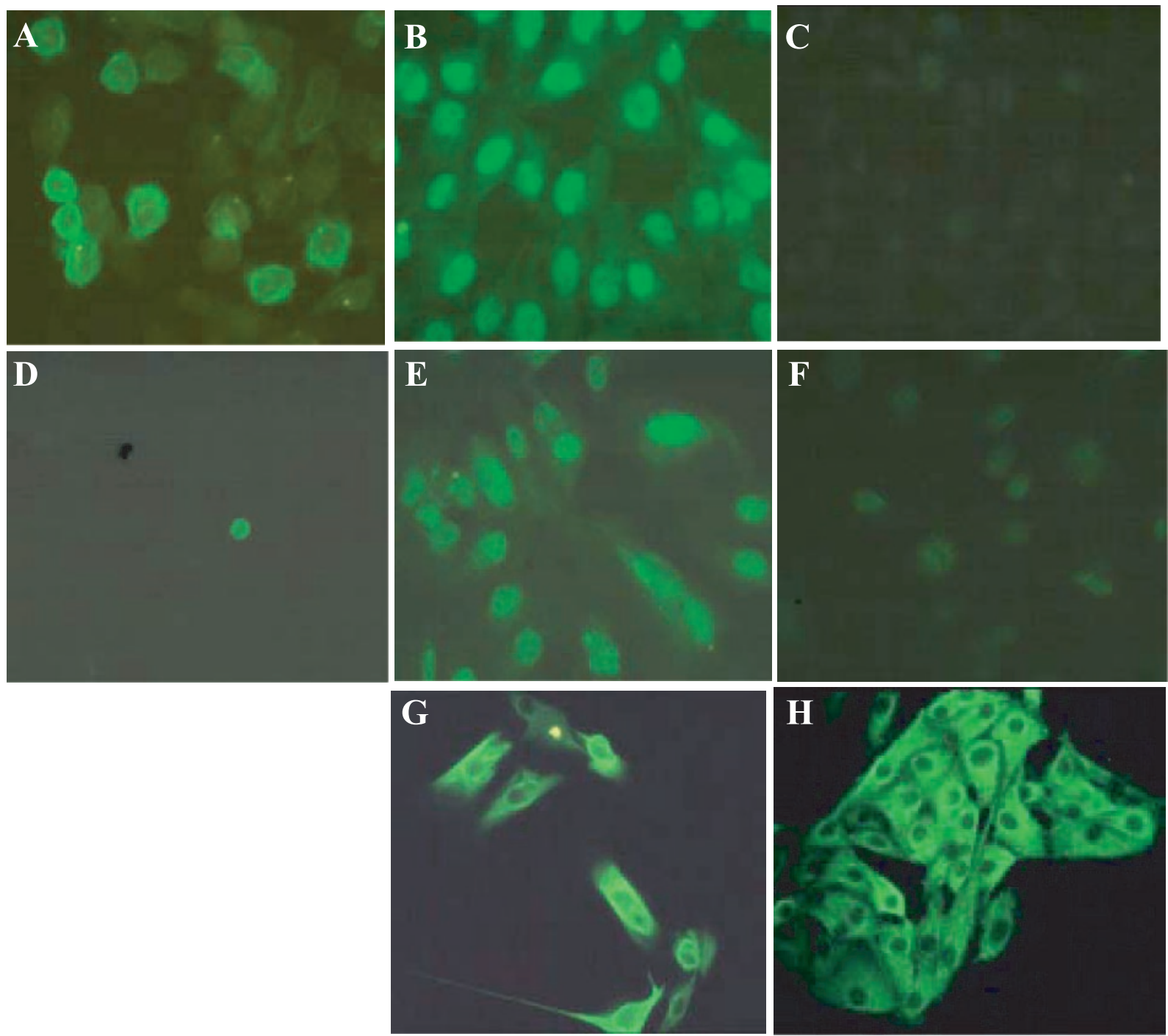

Fig. 5. Demonstration of tubule origin of cyst-derived cells. The cells were grown on collagen I-coated coverslips and either incubated with FITC-labeled D. biflorus (DBA), Arachis hypogaea (PNA), or L. tetragonolobus agglutinin (LTA) lectin or with an antibody to aminopeptidase N (CD13), followed by incubation with a FITC-labeled second antibody. A: cyst-derived cells of proximal tubule origin (WT 9-7) showing positive staining for CD13. B: cyst-derived cells of distal tubule origin (WT 10-7), showing positive staining with DBA lectin. C: WT 9-7 cells incubated with preimmune IgG as primary antibody (control for $A$ ). $D-F$ : control human renal cortical epithelial cells (WT RCTEC) of distal tubule origin, showing negative staining with CD13 $(D)$ and positive staining with DBA lectin $(E)$. Same cells incubated with preimmune IgG as primary antibody (control for $D$ ). $G$ : cyst-derived cells in primary culture showing positive staining with PNA lectin. $H$ : cyst-derived cells in primary culture showing positive staining with LTA lectin.

and $577.5 \Omega / \mathrm{cm}^{2}$ for $10-2,11-6$, and $14-2$, respectively (mean $1,270 \pm 485, n=3$ )]. After transformation, we were unable to show a significant difference in electrical resistance between the two cell types. For example, cell isolate 11-6 had electrical resistances of 1,645 and $2,764 \Omega / \mathrm{cm}^{2}$ on 2 consecutive days when in primary culture, which decreased to 89 and $134 \Omega / \mathrm{cm}^{2}$ (duplicate measures), when the measurements were repeated in transformed WT 11-6 cells. However, many other characteristic features of proximal and distal tubules could be identified in the immortalized ADPKD cell lines.

Electron microscopy. Electron microscopy was performed using cells grown on collagen I-coated filter inserts. The WT cells were grown at $37^{\circ} \mathrm{C}$ until confluency was reached. The TS cells were grown at $33^{\circ} \mathrm{C}$. When confluent, they were transferred to $37^{\circ} \mathrm{C}$ for 72 to $96 \mathrm{~h}$ before being processed for electron microscopy. The cells had large nuclei and appeared as polarized epithelial cells with the apical side facing the medium and the basolateral side facing the filter. We did not observe apical microvilli in these limited studies. Both cyst-derived cells in primary culture and the TS cells, studied after transfer to the nonpermissive temperature of $37^{\circ} \mathrm{C}$, showed relatively well-developed junctional complexes (Fig. 6). As reported in other immortalized cells (24), multilayering could be observed when the cells were grown under suboptimal conditions. 
A

Fig. 6. Transmission electron micrographs of immortalized cyst-derived cells. The cells were grown on collagen I-coated permeable filters and processed for electron microscopy. The TS cells were grown initially at $33^{\circ} \mathrm{C}$ and then switched to $37^{\circ} \mathrm{C}$ for $96 \mathrm{~h}$ before processing. $A$ : section from a cyst-derived cell in primary culture showing polarized appearance and a well-developed tight junction (arrows; magnification $\times 19,800$ before reduction). $B$ and $C$ : TS cells studied $96 \mathrm{~h}$ after transfer to $37^{\circ} \mathrm{C}$. B: two TS cells showing the presence of tight junctions between them (arrows). C: another area from the same filter, showing junctional complex between 2 cells (arrowhead). Magnification for $B$ and $C: \times 15,000$.

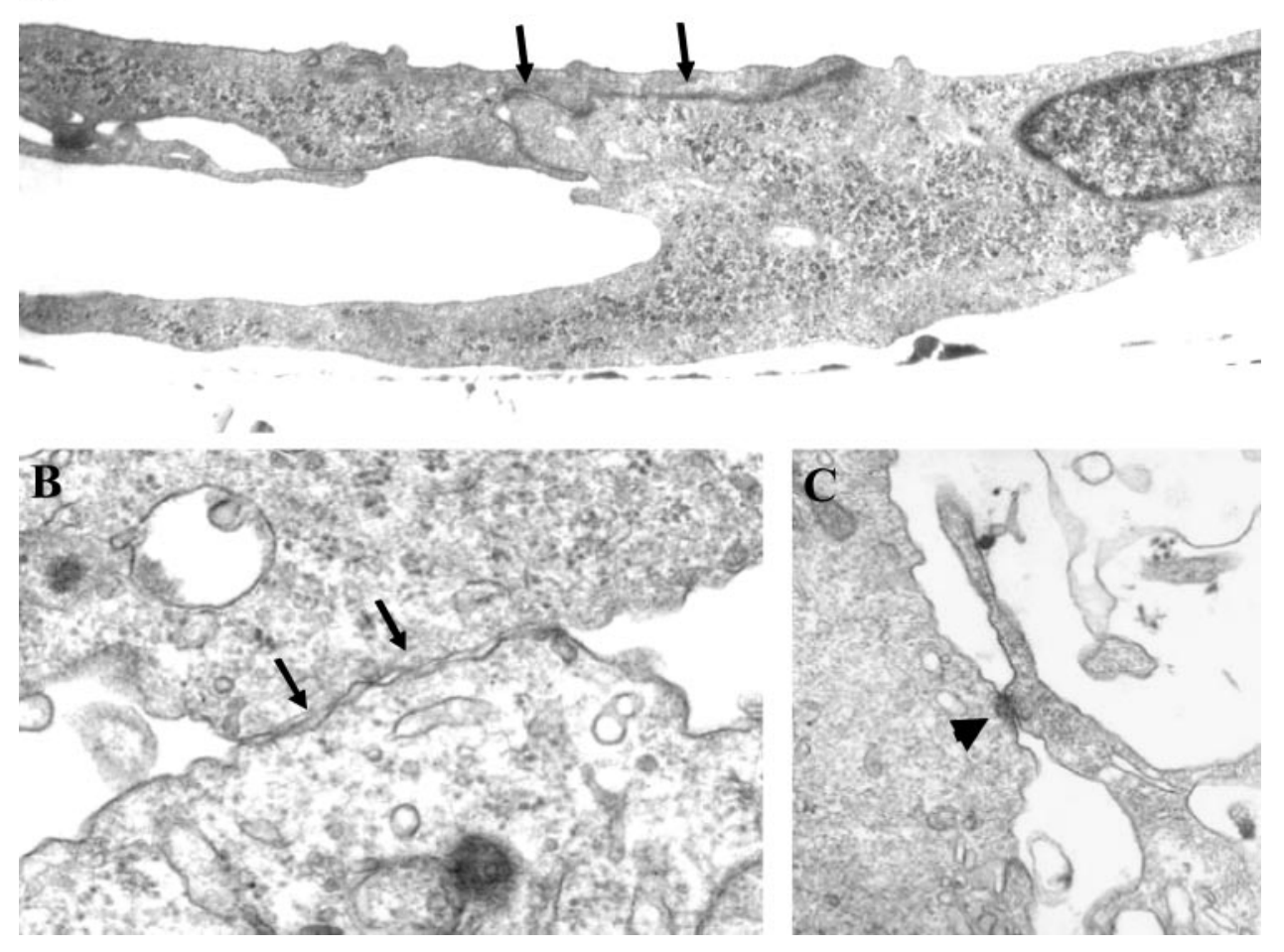

Hormonal responses. The generation of cAMP in response to hormones such as PTH and AVP has been used to ascertain the tubule origin of cultured renal cortical cells (26). Previous studies in cyst-derived cells in primary culture of unknown tubule origin showed reduced cAMP generation in response to PTH and AVP (43). With the use of immortalized cyst-derived cells with defined tubule origin, we investigated the effect of PTH and AVP on intracellular cAMP generation. As expected, there was a significant increase in intracellular cAMP, following exposure to forskolin $\left(10^{-5} \mathrm{M}\right)$ in all the cells tested (Fig. 7). In four experiments conducted in triplicate, we showed no change in intracellular cAMP generation in response to AVP in a cell line (WT 10-7) derived from a cyst of distal tubule origin. In contrast, we observed a significant increase in intracellular cAMP in response to PTH in a cell line (WT 9-7) derived from a cyst of proximal tubule origin $(P<$ $0.005, n=4)$. Interestingly, there was also a significant increase in cAMP in response to AVP in this cyst cell line of proximal tubule origin $(P<0.05, n=4)$. We observed increased intracellular cAMP (from $1.19 \pm$ 0.03 to $2.47 \pm 0.70 \mathrm{pmol} / \mathrm{well}, n=3$ ) in response to AVP in the distal tubule control human kidney cell line (WT RCTEC). However, the increase was significant only at $P=0.051$, perhaps due to intra-assay variability (Fig. 7). On the basis of these experiments, we conclude that there is a blunted response to AVP in cyst-derived cells of distal tubule origin, whereas the response of cyst-derived cells of proximal tubule origin to PTH remains intact.

Expression of polycystin-1 and polycystin-2. We used both RT-PCR and immunocytochemistry to determine the distribution of PKD1 and PKD2 mRNA and polycystin proteins from several cyst-derived cell lines. By semiquantitative RT-PCR, we showed the presence of mRNA for PKD1 and PKD2 in all cells examined (Fig. 8). Furthermore, both PKD1 and PKD2 band intensities appeared to be higher in cells grown on collagen I, compared with cells grown on plastic. With the use of polyclonal antibodies against polycystin- 1 and polycystin-2, we showed the presence of both proteins in all the cells examined. Both polycystin- 1 and polycystin-2 showed a diffuse intracytoplasmic staining pattern, regardless of the degree of confluence of the cell monolayer (Fig. 9). We also detected moderate staining for both polycystin- 1 and -2 in the control RCTEC cell lines (Fig. 9 and Table 1), indicating that the antibodies cannot distinguish between intact and mutated polycystins.

Expression of tubule-specific channels and proteins. In addition to polycystins, the immortalized cells express a variety of other markers typically associated with renal tubules. We studied the expression of mRNA for the genes of interest in selected cyst-derived cells as well as in human RCTEC using RT-PCR. They included the mRNA for cystic fibrosis transmembrane conductance regulator (CFTR), epithelial $\mathrm{Na}^{+}$channel $(\mathrm{ENaC}), \mathrm{Na}^{+}-\mathrm{H}^{+}$exchanger (NHE3), aquaporin-1 (AQP1), and $\mathrm{H}^{+}$-ATPase (Figs. 10 and 11). The epidermal growth factor receptor (EGF-R) was demonstrated both by RT-PCR and immunocytochemistry and was expressed by cyst-derived cells, of both proximal and distal tubule origin (Table 1). NHE3 was weakly expressed in cyst-derived cells, but strong NHE3 bands were seen in RCTEC lines. AQP1 was expressed in 
A

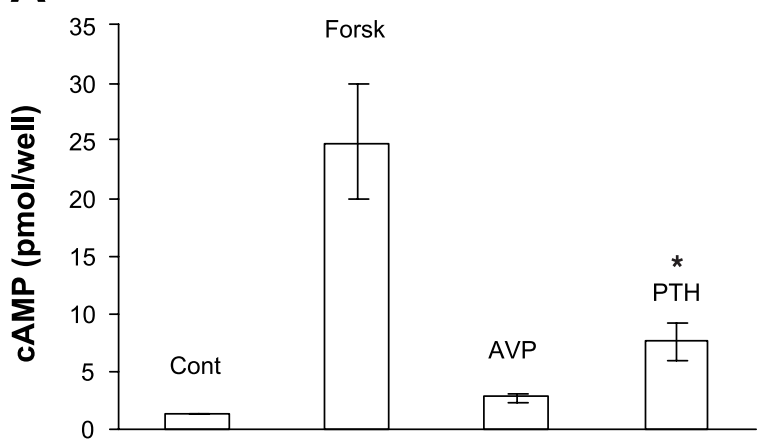

B
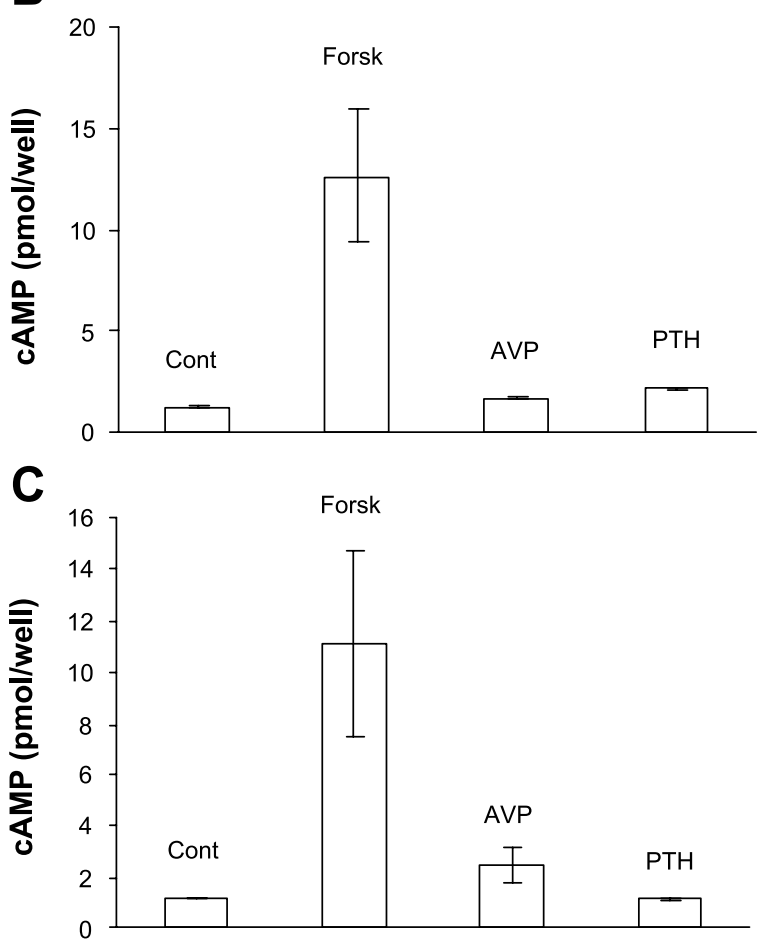

Fig. 7. cAMP generation by immortalized cyst-derived cells. The cells were incubated with forskolin (Forsk; $\left.10^{-5} \mathrm{M}\right)$, AVP $\left(10^{-6} \mathrm{M}\right)$, or parathyroid hormone (PTH; 1-34) $\left(10^{-6} \mathrm{M}\right)$ in the presence of $0.5 \mathrm{mM}$ 3-isobutyl-1 methylxanthine. Intracellular cAMP generated was measured by radioimmunoassay. Forskolin results in marked increase in cAMP in all the cell lines. A: cyst-derived cells of proximal tubule origin (WT 9-9) show increase in intracellular cAMP in response to both AVP and PTH. B: cyst-derived cells of distal tubule origin (WT 10-7) fail to respond to AVP. WT RCTEC shows moderate increase in cAMP in response to AVP. The results are means $\pm \mathrm{SE}$ of 3-4 experiments, each conducted in triplicate. $A$ : significance at $* P<$ 0.005. B: for WT 10-7, the difference between AVP or PTH and control was not significant. $C$ : for WT RCTEC, the difference between AVP and control did not reach statistical significance $(P=0.051)$.

cyst-derived cells of both proximal and distal tubule characteristics as well as in RCTEC lines. $\mathrm{H}^{+}$-ATPase was weakly expressed by cyst-derived cells of distal origin, but a strong band was seen in distal RCTEC. On the basis of these limited experiments, we conclude that the immortalized cyst-derived cells maintain many features of their tubule of origin. Interestingly, we showed that cyst-derived cells of distal tubule origin express renin, whereas the cyst-derived cells of proxi- mal tubule origin express angiotensinogen (43). Both cell types express angiotensin-converting enzyme and ANG I receptors ( $\mathrm{AT}_{1}$ subtype) (unpublished observations).

Immortalized cyst-derived cells express the SV40 large $T$ antigen. Because all the cyst-derived cell lines and the control human renal cortical cell line were immortalized with adeno-SV40 recombinant viral constructs, we verified the expression of SV40 large T antigen in these cells. We initially used immunocytochemistry with a monoclonal antibody against the large T antigen of SV40. Strong immunostaining was observed within the nucleus of all the cells studied (both ADPKD and RCTEC). In TS cells grown at the permissive temperature of $33^{\circ} \mathrm{C}$, the intensity of the large $\mathrm{T}$ antigen staining was similar to that found in WT cells grown at $37^{\circ} \mathrm{C}$. When the TS cells were switched to the nonpermissive temperature of $39^{\circ} \mathrm{C}$, the large $\mathrm{T}$ antigen staining was markedly reduced at $72 \mathrm{~h}$ (Fig. 12). In additional experiments, we tested for the presence of the SV40 large T antigen by Western blot analysis of cell lysates obtained from representative cyst-derived cells. The large $\mathrm{T}$ antigen was seen as a $94-\mathrm{kDa}$ band in WT cells grown at $37^{\circ} \mathrm{C}$ and in TS cells grown at $33^{\circ} \mathrm{C}$. There was a gradual decrease in the intensity of the large $\mathrm{T}$ antigen band in TS cells switched to $39^{\circ} \mathrm{C}$, which completely disappeared after $72 \mathrm{~h}$ (Fig. 13).

Demonstration of SV40 DNA incorporation into the cellular genome. Previous studies showed that human cells are relatively resistant to immortalization with SV40 oncogenes, whereas rodent cells can be easily transformed and immortalized (17). The $\left(\right.$ ori $\left.^{-}\right)$chimeric adeno-SV40 viruses such as the ones used in this study result in much higher efficiency of transformation compared with WT SV40 virus or with $\left(\right.$ ori $^{-}$) SV40

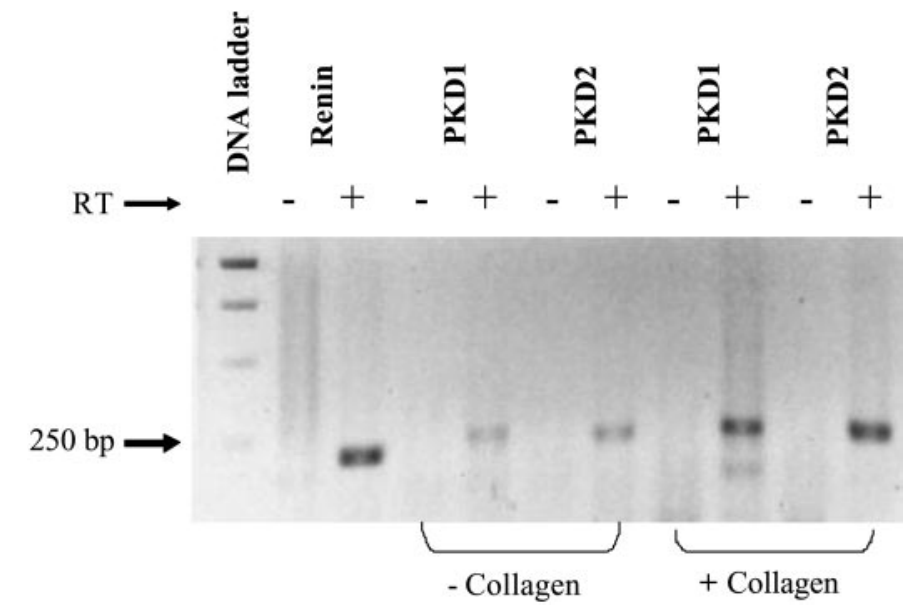

Fig. 8. Demonstration of mRNA for PKD1 and PKD2 in immortalized cyst-derived cells. Cyst-derived cells (WT 1-2) were grown on either noncoated or on collagen I-coated culture dishes, followed by RNA isolation. RT-PCR was performed, using specific primers for human PKD1 and PKD2 genes. Strong PKD1 and PKD2 mRNA bands are seen when the cells are grown on collagen. Weaker PKD1 and PKD2 mRNA bands are seen when the cells are grown on uncoated plastic. Note that these cells also express renin mRNA, which is not normally expressed in renal tubules. 

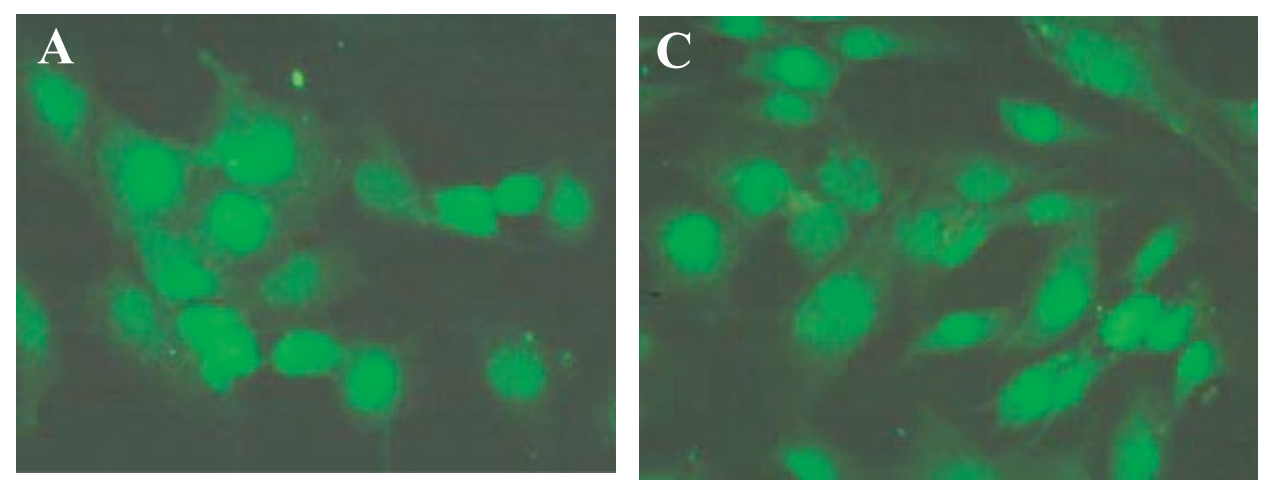

Fig. 9. Polycystin expression by immortalized cyst-derived and control human kidney cells. The cells were seeded on collagen I-coated coverslips and used for immunocytochemistry. Cells from a cyst of proximal tubule origin (WT 9-7) showing diffuse staining for polycystin-1 $(A)$ and polycystin-2 $(B)$. Cells from a cyst of distal tubule origin (WT 10-7) showing diffuse staining for polycysin-1 $(C)$ and polycystin-2 $(D)$. WT RCTEC cells showing staining for polycystin-1 $(E)$ and for polycystin-2 $(F)$. G: WT RCTEC cells stained with preimmune IgG showing background staining. A-G: magnification $\times 200$.
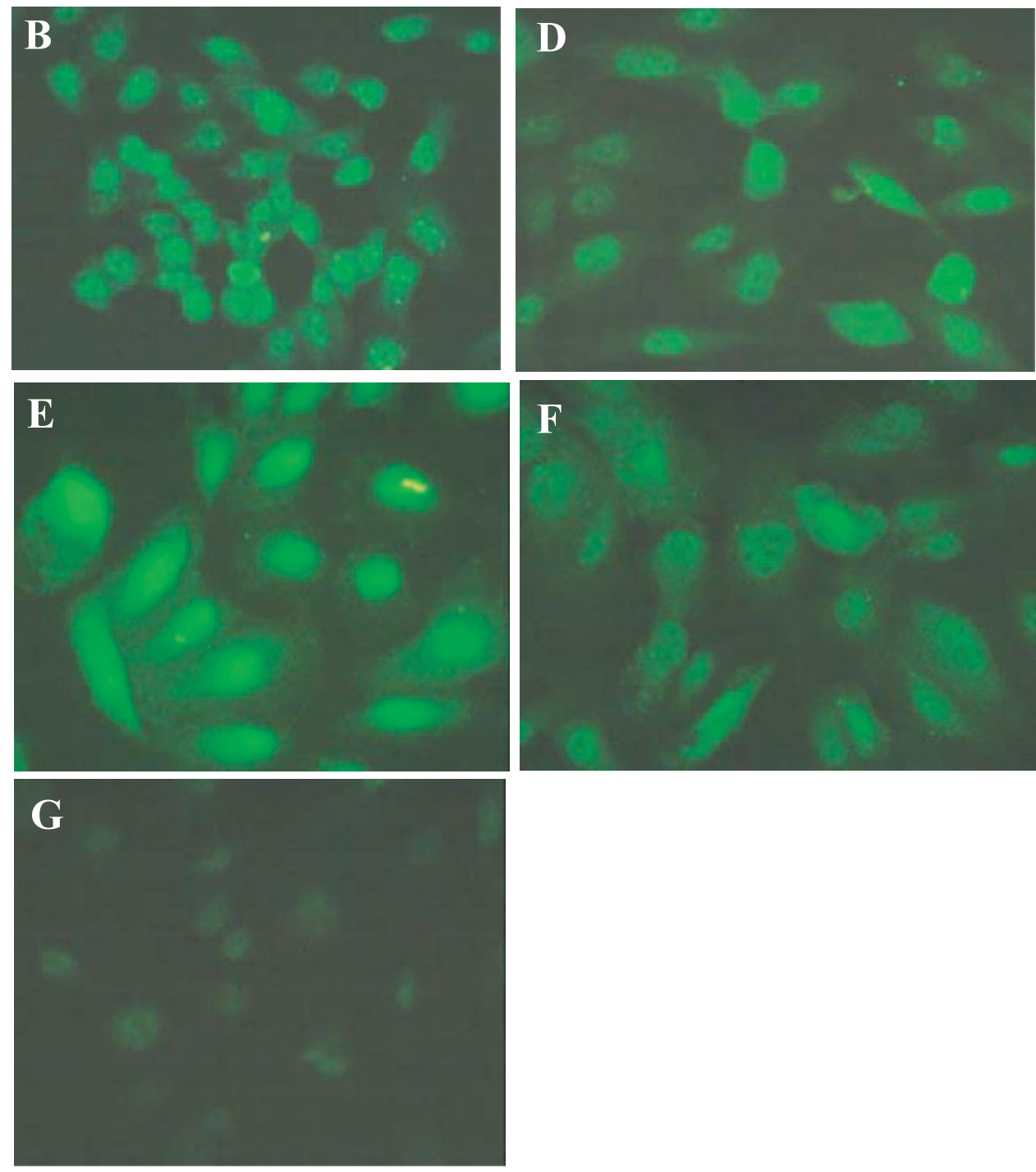

virus $(25,38)$. This was the reason for using the chimeric viruses instead of simple (ori ${ }^{-}$) SV40.

To ascertain that the cell lines have been successfully transformed, we studied the incorporation of SV40 DNA into the cyst-derived cellular DNA using PCR amplification. Because the TS SV40 virus used (TS A209) differs from the WT by a point mutation, the same PCR primers were used to amplify the genomic DNA obtained from both WT and TS cells. The results show the presence of a strong band for SV40 DNA in all cells tested, including the control RCTEC and cystderived cell lines (Fig. 14).

\section{DISCUSSION}

In ADPKD, cysts develop as a result of "second hit" somatic mutations in the normal or WT allele of the PKD1 or PKD2 gene, resulting in inactivation of the 


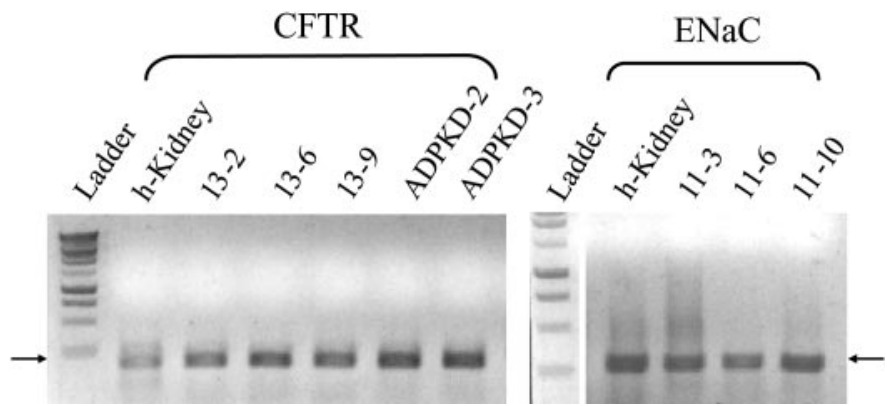

Fig. 10. Demonstration of mRNA for cystic fibrosis transmembrane conductance regulator (CFTR) and epithelial $\mathrm{Na}^{+}$channel $(\mathrm{ENaC}$; $\beta$-subunit) in immortalized cyst-derived cells. RT-PCR was performed using RNA isolated from several cells derived from single cysts of distal tubule origin. Autosomal dominant polycystic kidney disease (ADPKD)-2 and -3 cells were obtained from cystic tissue dissected from deep portions of ADPKD kidneys. Human kidney RNA was used as positive control. Strong mRNA bands are seen in all the cells tested (arrows).

gene and production of a nonfunctional protein $(22,36)$. A variety of mutations has been described in PKD1 and PKD2 families $(30,41)$. Because the cells described here were isolated from individual cysts, each cell line is likely to have a different somatic mutation resulting in a unique genotype. Therefore, these cell lines will be very useful for studies of the genotype-phenotype relationship, including studies aimed at rescuing the defective gene mutation by overexpressing the WT PKD1 or PKD2 genes. Studies are planned to obtain genotype analysis of all the cell lines described.
Primary cultures of cyst-derived cells have been used by a number of investigators $(28,29,43)$. The cells grow well initially and can be passaged up to three times. However, most experiments must be conducted by the second passage, as the growth slows significantly afterward. Accordingly, the cells must be obtained from cysts of freshly harvested polycystic kidneys, which considerably limits the availability of such cells. Using cyst-derived cells obtained from different kidneys with presumably different PKD mutations introduces significant experimental variability. The isolation of cells obtained from single cysts results in a high likelihood that each cell isolate has a defined tubule of origin (proximal or distal).

We describe the development and characterization of a series of immortalized cell lines derived from individual cysts of ADPKD kidneys and control cell lines from normal human kidney cortex. About half of the cell lines are conditionally immortalized with a TS SV40 virus and the rest immortalized with WT SV40 virus (Table 1). These immortalized cyst-derived cells offer several advantages. 1) They can be maintained in culture and used for long periods of time, thus eliminating the experimental variability associated with the use of cells derived from different ADPKD kidneys. 2) They obviate the need for scarce fresh human ADPKD kidneys for cell isolation. 3) They allow experiments to be planned ahead of time and to be performed in a controlled manner at the investigator's convenience. 4) Identical cell lines can be distributed among many
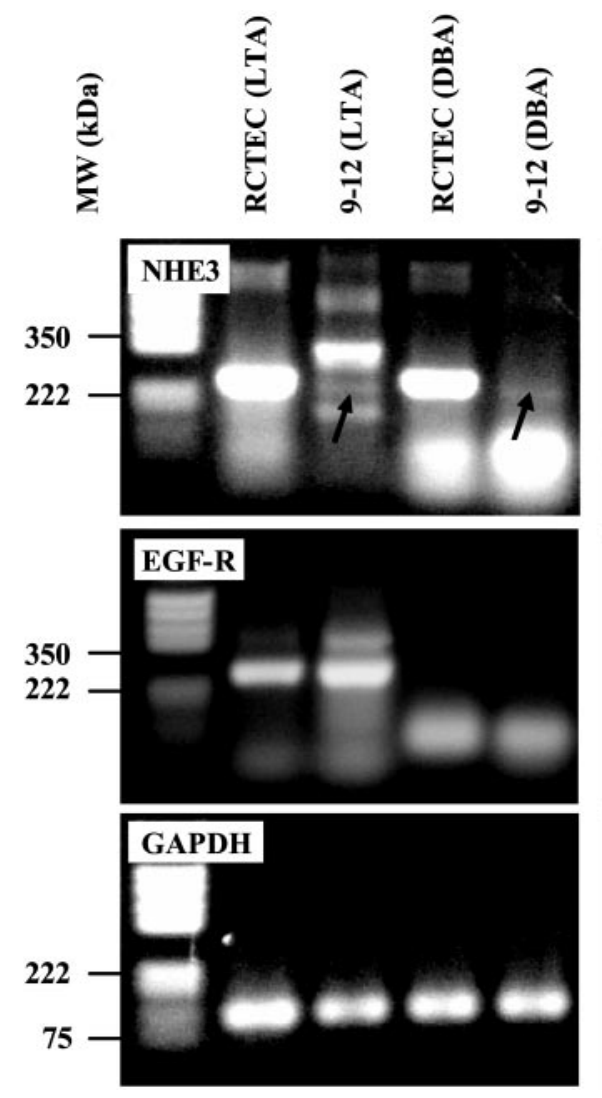
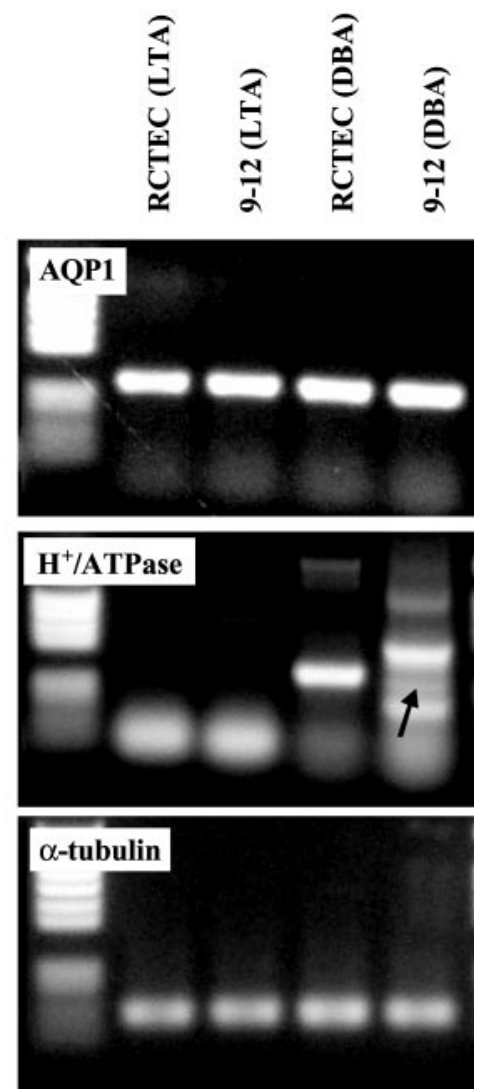

Fig. 11. Demonstration of mRNA for renal tubule-associated channels and proteins. Agarose gel of RT-PCRamplified products corresponding to $\mathrm{Na}^{+}-\mathrm{H}^{+}$exchanger (NHE3), aquaporin-1 (AQP1), epidermal growth factor receptor (EGF-R), and $\mathrm{H}^{+}$-ATPase $\beta_{1}$-subunit. GAPDH and $\alpha$-tubulin are used as positive controls. WT 9-12 LTA and WT 9-12 DBA were subcloned from a cystderived cell line, based on lectin-binding characteristics. WT 9-2 LTA has proximal tubule characteristics and WT 9-12 DBA has distal tubule characteristics. Similarly, WT RCTEC cells were subcloned into proximal tubule (RCTEC LTA) and distal tubule (RCTEC DBA) cell lines. Weak NHE3 bands are seen in both cyst-derived cells, whereas AQP1 is present in all cells. EGF-R band intensity is stronger in cells of proximal tubule origin. Conversely, $\mathrm{H}^{+}$-ATPase mRNA band is seen primarily in distal RCTEC and weakly in distal cyst-derived cells. MW, molecular weight. 

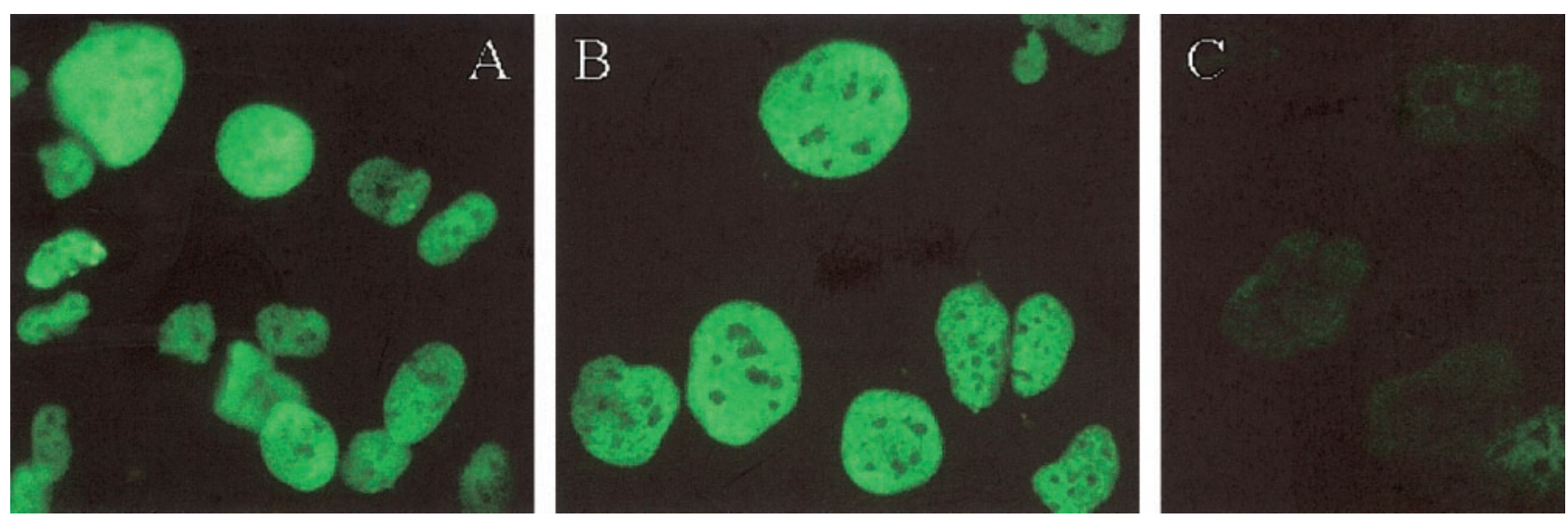

Fig. 12. Detection of simian virus (SV)40 large T antigen in immortalized cyst-derived cells. The cells were seeded on collagen-coated coverslips and used for immunocytochemistry with an antibody to the large T antigen of SV40. The WT cells (WT 9-7) were studied at $37^{\circ} \mathrm{C}$. The TS cells (TS 11-7) were studied both at $33^{\circ} \mathrm{C}$ and after transfer to $39^{\circ} \mathrm{C}$ for $72 \mathrm{~h}$. Strong large T antigen immunostaining is localized to the nuclei of cells in both WT and TS cells. The $\mathrm{T}$ antigen staining intensity is significantly reduced in TS cells kept at $39^{\circ} \mathrm{C}$ for $72 \mathrm{~h}$. C: apparent persistence of immunofluorescence signal is due to computer enhancement. All pictures were taken at 8-s exposure.

investigators, allowing comparison of the data between different laboratories and establishment of collaborative studies. 5) They facilitate detailed studies of the genotype-phenotype relationship by allowing comparisons between cells derived from different cysts of the same kidney or cells derived from cysts of different kidneys. 6) Immortalized cells can be stably transfected with expression vectors, using antibiotic selection, to obtain continued expression of a variety of genes and proteins. Such studies have, until now, been possible only in non-ADPKD cell lines such as MadinDarby canine kidney cells. The availability of control human kidney cell lines immortalized with the same SV40 viruses further increases the value of these cystderived cell lines as experimental models of ADPKD.

The cell lines were derived from individual cysts of 11 ADPKD kidneys by infecting the primary cyst-derived cell cultures with both WT and TS adeno-SV40 recombinant viruses. Thirty cyst-derived cells in primary culture were used, of which 10 were immortalized with WT SV40 virus, 9 were immortalized with TS

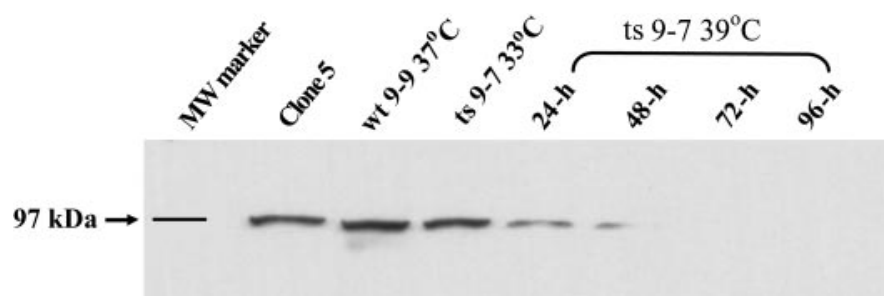

Fig. 13. Detection of SV40 large T antigen in immortalized cystderived cells. The cells were grown either at $37^{\circ} \mathrm{C}$ (WT 9-9 cells) or at $33^{\circ} \mathrm{C}$ (TS 9-7 cells) and then transferred to $39^{\circ} \mathrm{C}$ for different times before collection. Cell culture media were collected at times indicated and used for SDS-PAGE, followed by Western blotting. The large T antigen is seen as a band of $94-\mathrm{kDa}$ molecular mass. Clone 5 is a murine collecting duct cell line derived from a transgenic mouse (tsA58) harboring the SV40 large $\mathrm{T}$ antigen gene. The $\mathrm{T}$ antigen band is seen in WT cells at $37^{\circ} \mathrm{C}$ and in TS cells at $33^{\circ} \mathrm{C}$. It completely disappears $72 \mathrm{~h}$ after transfer of the TS 9-7 cells to $39^{\circ} \mathrm{C}$.
SV40 virus, and 11 were immortalized with both WT and TS viruses (Table 1).

SV40 has been used successfully to transform a variety of cells and prolong their life span (9). Small et al. (33) showed that the frequency of transformation can be enhanced with the use of SV40 ori- mutants. Human cells are semipermissive for SV40 viruses, and viral replication occurs in $\sim 1-2 \%$ of the cells (38). A portion of the cell population can become transformed and integrate the viral DNA into the cell genome (38). However, successful transformation and subsequent immortalization occur rarely even when ori $^{-}$SV40 viruses are used (25). To overcome these limitations, chimeric adenovirus-ori- ${ }^{-}$SV40 recombinants have been developed (38). They contain an ori ${ }^{-}$SV40 DNA cloned into the adenovirus vector in place of early
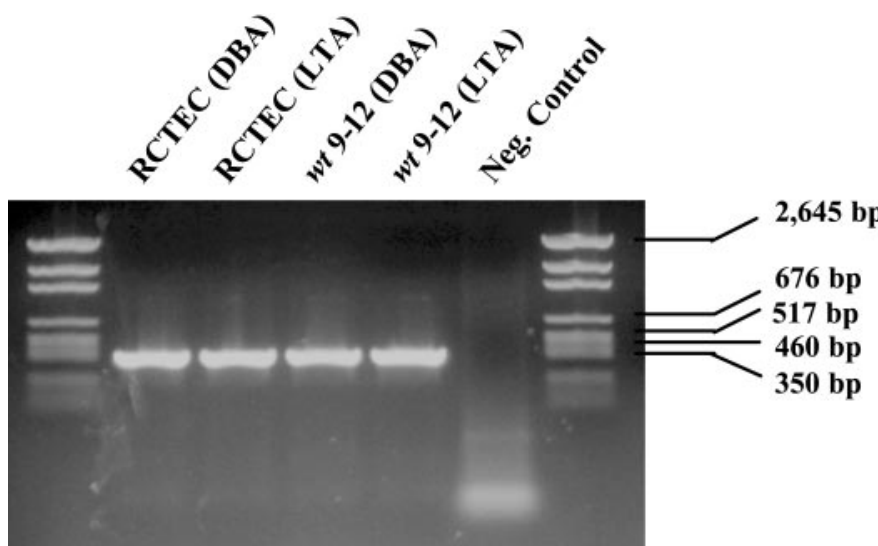

Fig. 14. Demonstration of integration of SV40 DNA into cell genome. Agarose gel of PCR products obtained from genomic DNA isolated from 2 immortalized cyst-derived cell lines of proximal (WT 9-12 LTA) and distal (WT 9-12 DBA) tubule origin as well as from 2 immortalized control human renal proximal and distal tubule cell lines (RCTEC LTA and RCTEC DBA) is shown. SV40 DNA is seen as a 421-bp band in all the cells studied, confirming the integration of viral DNA into the cell genome. 
regions $1 \mathrm{a}$ and $1 \mathrm{~b}$. In previous studies, no transcripts of adenovirus early regions were detected in cells transformed by hybrid adeno-SV40 viruses (32). Therefore, the adenovirus acts as a vehicle and not as the transforming agent. Because it lacks the early region 1 , the adenovirus does not replicate inside the cells $(32,38)$.

Successful transformation of cyst-derived cell lines was confirmed by observing continued cell division beyond the third passage and, more specifically, by demonstrating the presence of the SV40 large T antigen protein within the nucleus of the cells and the integration of SV40 DNA within the host cell DNA. Because of the unique structure of the recombinant adeno-SV40 viral construct used, the amplified SV40 DNA most likely represents chromosomal DNA and not free DNA (38). We further showed that the TS form of the large $\mathrm{T}$ antigen undergoes degradation and disappears in cells grown for at least $72 \mathrm{~h}$ at the nonpermissive temperature of $39^{\circ} \mathrm{C}$. Large $\mathrm{T}$ antigen degradation was also observed at the more convenient temperature of $37^{\circ} \mathrm{C}$. The loss of the $\mathrm{T}$ antigen has been generally associated with a more differentiated phenotype $(9,26)$. Differentiation may also be improved by growing the cells on collagen-coated plates, instead of plastic. For example, we showed that renin mRNA expression is higher in cyst-derived cells grown on collagen compared with those grown on plastic (unpublished observations). The expression of PKD1 and PKD2 mRNA is also increased in cyst cells grown on collagen-coated plates (Fig. 8).

In some experiments, the expression of SV40 large T antigen may be used to an advantage. Because the $T / t$ common exon of SV40 can functionally replace the $\mathrm{J}$ domain of molecular chaperones, continued expression of the SV40 large T may facilitate membrane translocation of channel proteins such as polycystins $(21,39)$. Pairs of cyst-derived cells, transformed with both WT and TS SV40 viruses, offer the ability to test the effect of large $\mathrm{T}$ antigen on intracellular localization of polycystin- 1 and polycystin-2.

Although we observed high transepithelial electrical resistance across some cyst-derived cells in primary culture, lower electrical resistances were recorded after the cells had been immortalized. The reason transepithelial electrical resistance declines is not clear but may be related to reduced differentiation after immortalization or the possibility that the cell could be of proximal tubule origin. Among the cell lines, only a few TS cells were tested. Therefore, additional studies are needed to test all the cells under conditions that would induce maximum differentiation (nonpermissive temperature, appropriate substratum). It is possible that under optimal conditions, the immortalized cyst-derived cells of distal origin might develop higher transepithelial electrical resistance close to values seen in cells in primary culture.

The immortalized cyst-derived cells maintain the expression of some channels and proteins present on renal tubular epithelial cells. These include proximal tubule markers such as angiotensinogen (37), AQP1 (11) or NHE3 (5), and distal tubule and collecting duct markers such as ENaC (24) and CFTR (20). The cystderived cells also maintain the expression of the EGF-R. Although the expression of channels in cystderived cells generally followed the pattern expected based on tubule origin, AQP1 and NHE3 were expressed in cyst-derived cells of both proximal and distal tubule origin. Additional studies are required to clarify this apparent discrepancy with previous reports (11). Of particular interest is the expression of renin and all the other components of the renin-angiotensin system by many cyst-derived cell lines (unpublished observations). Currently, there are no human kidney cell lines that express renin, making these cell lines useful for studies of renin regulation.

In summary, we developed two series of immortalized cell lines from cyst epithelium of individual cysts of 11 human ADPKD as well as immortalized control cell lines from normal human renal cortex. One line of cells was immortalized with a WT adeno-SV40 virus, resulting in continued expression of the SV40 large T antigen. Another line of cells was immortalized with a TS adeno-SV40 virus, in which the large $\mathrm{T}$ antigen can be turned off when the cells are transferred to a nonpermissive temperature, resulting in a more differentiated phenotype. These new cell lines should facilitate studies of the mechanism of cyst formation including cell proliferation, cell-cell or cell-matrix interaction, signal transduction, and genotype-phenotype correlation.

The authors thank Dr. J. Ryerse, Dept. of Pathology, St. Louis University, for performing the electron microscopy.

\section{DISCLOSURES}

This study was supported in part by grants from the National Institutes of Health (to J. Zhou) and by grants from Polycystic Kidney Research Foundation and the Fleur-de-Lis Foundation (to M. Loghman-Adham). S. M. Nauli was supported by a postdoctoral fellowship from the Polycystic Kidney Research Foundation. The shipping of nephrectomy specimens from various surgical programs was facilitated by the PKD Foundation and by patients and surgical specialists who offered to participate in the study.

\section{REFERENCES}

1. Araki K, Ohashi Y, Sasabe T, Kinoshita S, Hayashi K, Yang XZ, Hosaka Y, Aizawa S, and Handa H. Immortalization of rabbit corneal epithelial cells by a recombinant SV40-adenovirus vector. Invest Ophthalmol Vis Sci 18: 2665-2671, 1993.

2. Arnaout A. Molecular genetics and pathogenesis of autosomal dominant polycystic kidney disease. Annu Rev Med 52: 93-123, 2001.

3. Baert L. Hereditary polycystic kidney disease (adult form): a microdissection study of two cases at an early stage of the disease. Kidney Int 13: 519-525, 1978.

4. Bello-Reuss E, Holubec K, and Pajaraman S. Angiogenesis in autosomal dominant polycystic kidney disease. Kidney Int 60: $37-45,2001$.

5. Biemesderfer D, Rutherford PA, Nagy T, Pizzonia JH, Abu-Alfa AK, and Aronson PS. Monocloncal antibodies for high-resolution localization of NHE3 in adult and neonatal rat kidney. Am J Physiol Renal Physiol 273: F289-F299, 1997.

6. Calvet JP and Grantham JJ. The genetics and physiology of polycystic kidney disease. Semin Nephrol 21: 107-123, 2001.

7. Chapman AB and Schrier RW. Pathogenesis of hypertension in autosomal dominant polycystic kidney disease. Semin Nephrol 11: 653-660, 1991. 
8. Chen XZ, Segal Y, Basora N, Guo L, Peng JB, Babakhanlou H, Vassilev PM, Brown EM, Hediger MA, and Zhou J. Transport function of the naturally occurring pathogenic polycystin-2 mutatnt R742X. Biochem Biophys Res Commun 282: 1251-1256, 2001.

9. Chou JY. Differentiated mammalian cell lines immortalized by temperature-sensitive tumor viruses. Mol Endocrinol 3: 1511$1514,1989$.

10. Detrisac CJ, Sens MA, Garvin AJ, Spicer SS, and Sens DA. Tissue culture of human kidney epithelial cells of proximal tubule origin. Kidney Int 25: 383-390, 1984.

11. Devuyst O, Burrow CR, Smith BL, Agre P, Knepper MA, and Wilson PD. Expression of aquaporin-1 and -2 during nephrogenesis and in autosomal dominant polycystic kidney disease. Am J Physiol Renal Fluid Electrolyte Physiol 271: F169-F183, 1996.

12. Faraggiana T, Bernstein J, Strauss L, and Churg J. Use of lectins in the study of histogenesis of renal cysts. Lab Invest 53: $575-579,1985$.

13. Foggensteiner L, Bevan AP, Thomas R, Coleman N, Boulter C, Bradley J, Ibraghimov-Beskrovnaya O, Klinger $\mathbf{K}$, and Sandford R. Cellular and subcellular distribution of polycystin-2, the protein product of the PKD2 gene. J Am Soc Nephrol 11: 814-827, 2000.

14. Geng L, Segal Y, Peissel B, Deng N, Pei Y, Carone F, Rennke HG, Glucksmann-Kuis AM, Schneider MC, Ericsson M, Reeders ST, and Zhou J. Identification and localization of polycystin, the PKD1 gene product. J Clin Invest 98: 2674-2682, 1996

15. Gonzalez-Perrett S, Kim K, Ibarra C, Damiano AE, Zotta E, Batelli M, Harris PC, Reisin IL, Arnaout MA, and Cantiello HF. Polycystin-2, the protein mutated in autosomal dominant polycystic kidney disease (ADPKD), is a $\mathrm{Ca}^{2+}$-permeable nonselective cation channel. Proc Natl Acad Sci USA 98: 1182 1187, 2001.

16. Grantham JJ. Polycystic kidney disease: a predominance of giant nephrons. Am J Physiol Renal Fluid Electrolyte Physiol 244: F3-F10, 1983.

17. Hahn WC, Counter CM, Lundberg AS, Beijersbergen RL, Brooks MW, and Weinberg RA. Creation of human tumour cells with defined genetic elements. Nature 400: 464-468, 1999.

18. Hanaoka K, Qian F, Boletta A, Bhunia A, Piontek K, Tsiokas L, Sukhatme VP, Guggino WB, and Germino GG. Coassembly of polycystin-1 and -2 produces unique cation-permeable currents. Nature 408: 990-994, 2000

19. Harris PC. Autosomal dominant polycystic kidney disease: clues to pathogenesis. Hum Mol Genet 8: 1861-1866, 1999.

20. Husted RF, Volk KA, Sigmund RD, and Stokes JB. Anion secretion by the inner medullary collecting duct. Evidence for involvement of the cystic fibrosis transmembrane conductance regulator. J Clin Invest 95: 644-650, 1995.

21. Kelley WL and Georgopoulos C. The T/t common exon of simian virus 40 , JC and BK polyomavirus $\mathrm{T}$ antigens can functionally replace the J-domain of the Escherichia coli DNA J molecular chaperone. Proc Natl Acad Sci USA 94: 3679-3684, 1997.

22. Koptides M and Deltas CC. Autosomal dominant polycystic kidney disease: molecular genetics and molecular pathogenesis. Hum Genet 107: 115-126, 2000.

23. Laemmli UK. Cleavage of structural proteins during the assembly of the head of bacteriophage T4. Nature 227: 680-685, 1970.

24. Lagger Biner H, Arpin-Bott MP, Loffing J, Wang X, Knepper M, Hebert SC, and Kaissling B. Human cortical distal nephron: distribution of electrolyte and water transport pathways. J Am Soc Nephrol 13: 836-847, 2002.

25. Lei KJ, Gluzman Y, and Chou JY. Immortalization of virusfree human placental cells that express tissue-specific functions. Mol Endocrinol 6: 703-712, 1992.

26. Loghman-Adham M, Rohrwasser A, Helin C, Zhang S, Terreros D, Inoue I, and Lalouel JM. A conditionally immor- talized cell line from murine proximal tubule. Kidney Int 52: 229-239, 1997.

28. Mangoo-Karim R, Ye M, Wallace DP, Grantham JJ, and Sullivan LP. Anion secretion drives fluid secretion by monolayers of cultured human polycystic cells. Am J Physiol Renal Fluid Electrolyte Physiol 269: F381-F388, 1995.

29. McAteer JA, Carone FA, Grantham JJ, Kempson SA, Gardner KD, and Evan AP. Explant culture of human polycystic kidney. Lab Invest 59: 126-136, 1988.

30. Mochizuki T, Wu G, Hayashi T, Xenophontos SL, Veldhuisen B, Saris JJ, Reynolds DM, Cai Y, Gabow PA, Pierides A, Kimberling WJ, Breuning MH, Deltas CC, Peters DJM, and Somlo S. PKD2, a gene for polycystic kidney disease that encodes an integral membrane protein. Science 272 : 1339-1342, 1996.

31. Ong ACM, Ward CJ, Butler RJ, Biddolph S, Bowker C, Torra R, York P, and Harris PC. Coordinate expression of the autosomal dominant polycystic kidney disease protein, polycystin-2 and polycystin-1 in normal and cystic tissue. Am J Pathol 154: 1721-1729, 1999

32. Reddel RR, Ke Y, Gerwin BI, McMenamin MG, Lechner JF, Su RT, Brash DE, Park JB, Rhim JS, and Harris CC. Transformation of human bronchial epithelial cells by infection with SV40 or adenovirus-12 SV40 hybrid virus, or transfection via strontium phosphate coprecipitation with a plasmid containing SV40 early region genes. Cancer Res 48: 1904-1909, 1988.

33. Small MB, Gluzman Y, and Ozer HL. Enhanced transformation of human fibroblasts by origin-defective simian virus 40 . Nature 15: 671-672, 1982.

34. Taub M, Chuman L, Saier MH, and Sato G. Growth of Madin-Darby canine kidney epithelial cell (MDCK) line in hormone-supplemented, serum-free medium. Proc Natl Acad Sci USA 76: 3338-3342, 1979.

35. The International Polycystic Kidney Disease Consortium. Polycystic kidney disease: the complete structure of the PKD1 gene and its protein. Cell 81: 289-298, 1995.

36. Torra R, Badenas C, San Millan JL, Perez-Oller L, Estivill $\mathbf{X}$, and Darnell A. A loss of function model of cystogenesis in human autosomal dominant polycystic kidney disease type 2 . Am J Hum Genet 65: 345-352, 1999.

37. Towbin HT, Staehelin T, and Gordon J. Electrophoretic transfer of proteins from polyacrylamide gels to nitrocellulose sheets: procedure and some applications. Proc Natl Acad Sci USA 76: 4350-4354, 1979.

38. Van Doren $\mathbf{K}$ and Gluzman Y. Efficient transformation of human fibroblasts by adenovirus-simian virus 40 recombinants. Mol Cell Biol 4: 1653-1656, 1984.

39. Vassilev PM, Guo L, Chen XZ, Segal Y, Peng JB, Basora N, Babakhanlou H, Gruger G, Kanazirska M, Ye CP, Brown EM, Hediger MA, and Zhou J. Polycystin-2 is a novel cation channel implicated in defective intracellular $\mathrm{Ca}^{2+}$ homeostasis in polycystic kidney disease. Biochem Biophys Res Commun 282: 341-350, 2001.

40. Ward CJ, Turley H, Ong ACM, Comley M, Biddolph S, Chetty R, Ratcliffe PJ, Gatter K, and Harris PC. Polycystin, the polycystic kidney disease 1 protein is expressed by epithelial cells in fetal, adult, and polycystic kidney. Proc Natl Acad Sci USA 93: 1524-1528, 1996.

41. Watnick T and Germino GG. Molecular basis of autosomal dominant polycystic kidney disease. Semin Nephrol 19: 327-343, 1999.

42. Wilson PD. Epithelial cell polarity and disease. Am J Physiol Renal Physiol 272: F434-F442, 1997.

43. Wilson PD, Schrier RW, Breckon RD, and Gabow PA. A new method for studying human polycystic kidney disease epithelia in culture. Kidney Int 30: 371-378, 1986.

44. Yaoita E, Franke WW, Yamamoto T, Kwasaki K, and Kihara I. Identification of renal podocytes in multiple species: higher vertebrates are vimentin positive/lower vertebrates are desmin positive. Histochem Cell Biol 111: 107-115, 1999. 